\title{
New Administration Systems for the World Countries and Sense of Justice \& Continuity in the System Administration
}

\author{
Refet Ramiz \\ Near East University, North Nicosia, North Cyprus, TRNC, Cyprus
}

\begin{abstract}
In this work, some of the results of the synthesis about the administration systems are expressed. The Author defined four new case theories and 23 main methods, and defined five general political/non-political administration system categories for the world countries. Each system is defined with the related 12 sub blocs to solve the general and specific problems of communities, territories, states and/or countries. Each bloc includes presidency, council, committees, associations and R-autonomous construction. For each of these five administration system categories, and for each of their sub blocs, general/specific system administration construction is defined with its 21 blocs. Importance of both sense of justice and continuity/sustainability are described with the related 21 categories defined for each of these perspective. Types of system administration are defined for five categories of administration systems. General and specific characteristics and possible fundamental and representative duties of country presidency system are defined. Ideal political constructions are defined for each of five general administration system categories. Specific way of integration of the past and present politic/non-politic groups into the ideal political construction is defined in multi dimensional form. Constructional centrism, R-Centrism, R-Continuity, R-Democracy, R-Ideology, R-Philosophy, R-Progressive, R-Religion, R-Science, Progressive Religion, ideal stability chart and some other concepts are defined as constructional and/or complementary basics of the systems. Author defined a criterion to measure the value of a country. Effective weight function of a world country is defined as a mathematical function to inspect, observe the performance and progression of a country inside, and/or in the region, and/or in the world. Basic forms of government are re-constructed and/or re-defined as hybrid-powers for each of these five categories of administration systems and general comparison made with the past/present ones. New political constructions are proposed for different party systems, different federation systems in the world. Applications and realization of the four new case theories and 23 main methods are expressed for all world countries. Author defined new or re-constructed 20 regional unions for the world due to new case theories, and one of them (SEAEU) is already officially declared.
\end{abstract}

Keywords: administrations and systems, sense of justice, unions, ideal political construction, political systems, administration and science

\section{Introduction}

In this work author expressed "some" of the results of the synthesis he made. This synthesis is realized by considering the 17 subjects generally/specifically (Ramiz, March 2016). With this respect, the synthesis include

Refet Ramiz, Assist. Professor, Department of Electrical and Electronic Eng.; Department of Political Science; Department of International Relations; Near East University. 
evaluation of the all ethnic origins (Ethnic groups, 2015; n.d.), federations (Federation, 2016), ideologies (Political ideologies, 2010), mythologies, organizations, organs of government, party systems (Party system, 2015), evaluation period, philosophies (Philosophy, 2015), political ideology spectrums (Political spectrum, 2015), political/non-political administration systems, politic power sources, politic power structures, public administrations, religions, sciences, and related personal and other different sources (Ramiz, March 2016).

As the author noticed as result of the synthesis and also expressed in other work partly (Ramiz, March 2016), some/most/all of the problems (due to subjects of services, see Ramiz, March 2016) in the world countries, are because of the past/present definitions, conflicts, differences, theories, or disputes about these subjects, and also about human beings, basic senses (good, bad, true, wrong), administrations, justice, and about other theoretical and/or practical subjects generally/specifically.

As result of the synthesis, it is defined that there are 17 basic important concepts for the political/non-political administration system of a world country (Ramiz, March 2016). The author considered these concepts and defined the possible solutions of the problems accordingly.

System administration is one of the important part of the political/non-political administration systems, and the administrator(s) is one of the main subject of the system administration(s). It is also important how an administrator is related with the system administration too. In general manner, the "system", "administrator person" and "information" triple can be a solution to some/most problems or cause problems in the political/non-political administration systems, together and/or separately. With this respect, it is important to define the "priority" for the consideration of the characteristics of these three effective parameters together. It is proposed that each of these effective parameter can have two possible characteristics/senses in simple manner; "good" or "bad". Under these considerations, it is possible to define following priorities for continuable/sustainable administration system (see Table 1) with the highest to lowest level importance.

Table 1

Priorities for Continuable/Sustainable Administration System

(Due to Characteristics of the System, Administrator Person and Information Triple Together)

\begin{tabular}{llll}
\hline Levels & System & Administrator Person & Information \\
\hline 1 (Highest level) & Good & Good & Good \\
2 & Good & Good & Bad \\
3 & Bad & Good & Good \\
4 & Bad & Good & Bad \\
5 & Good & Bad & Good \\
6 & Good & Bad & Bad \\
7 & Bad & Bad & Good \\
8 (Lowest level) & Bad & Bad & Bad \\
\hline
\end{tabular}

Table 1 simply indicates the importance of "system", "administrator person" and "information", together and separately. Upon to the some subjects of services (Ramiz, March 2016), level-3 and 4 can interchange with level 5 and 6. This is something related with priority theory. However, more sensitive evaluation is done for 8-basic senses/characteristics (Ramiz, January 2016; Ramiz, March 2016), and by considering the 21-dimensions of the synthesis (Ramiz, March 2016), and the parameters of effective weight function (EW) which is defined in the following sections for a world country.

The purpose of this work, is to solve these problems for all related sides in a country and/or in the world to 
obtain continuable (political/non-political) administrative system(s) for the world countries by considering countries' union theory (Ramiz, March 2016) and other new methods and new theories. The author considered the "synthesis" method and evaluated, generally/specifically, all these subjects by considering nearly 12,000 years written historical period (Yücel, 1985; Gülaltay, 2005; others). The author also considered his personal direct/indirect contacts with nearly 80,000 (+) people (until May 2010), who are/were from different political/non-political groups, and from all different position levels, during his synthesis. Additionally some worldwide contacts which realized after May 2010 period are considered. With this respect, the meaning of the union is discussed and described, then 21 dimensions of the synthesis (Ramiz, March 2016) are defined to categorise the problems, and related solutions, and new theories found. General points that can be evaluate as positive and/or negative about each side are expressed. Basic important concepts and definitions about political/non-political administrations of a world country are defined. General types of organizations and administrations in the world are expressed together with some related problems in the present systems. Good and/or correct perspective that must be behind administration(s) is described (Ramiz, March 2016). Categories and types of interacted sides are explained. Thirty seven (37) subjects of services mandatory for a world country are defined (Ramiz, March 2016). Necessity of the new system(s) for two or more sides is expressed. General types of needs for each world country are defined and categorised due to the domestic and international needs and due to possible interaction between two or more sides. As a consequences, new political/non-political methods are defined (Ramiz, March 2016) to solve general and specific administrative problems between sides in a world country or between different countries. Theory of countries' union system is defined specifically in other work (Ramiz, March 2016). General principles and sense of justice which are necessary for establishing countries' union between any two countries are defined accordingly.

Although the seven important sections, eleven important sub-sections of the countries' union theory and political/non-political administration systems for the world countries are defined in other work (Ramiz, March 2016), this article includes eight other important sections, and twenty one sub important sections related with the new methods, new theories, and new systems. With this respect, the other work (Ramiz, March 2016) includes some basics about the countries' union theory and about political/non-political administration system design. The subjects defined in that work are important complemenatry subjects for this article, and that subjects should be evaluated together with the subjects given here for better understanding the sensitivity in design and the importance of the synthesis considered.

In this work, author considered the new methods and new theories (Ramiz, March 2016) for political/nonpolitical administration systems in the first section. And defined the four case theories and 23 main methods accordingly. Then constructional and/or complementary theories, ideologies, philosophies, sciences are given generally/specifcally, shortly. The new administration systems are defined in the second section for the world countries by considering five categories for administration systems. These categories are; (1) General Political Administration System for a World Country; (2) General Political Administration System for a Country Union; (3) General Political Administration System for a Countries' Union; (4) General Administration System for Regional Countries' Union; and (5) General Administration System for World Countries' Union.

Each system is defined with related blocs, and some general information is given for each bloc of the systems. Then, a general/specific "system administration" is defined for all categories of administration systems, and expressed with figure at the third section. As one of the unique side of the synthesis, it is 
considered that this system administration is applicable to all administration systems, and to all sub blocs of these systems.

The author also defined the sense of justice, which is part of the system administration structure, for all types of administration systems, and for all system administration with sensitive new theory. Importance of the sense of justice is described with the 21 categories defined generally/specifically. Continuity/sustainability theory is defined for all types of administration systems and for related system administrations. Then types of system administrations, new presidency system for a world country, ideal political construction for a world country, way of synthesis for a person, integration to the ideal political construction, constructional centrism, ideal stability chart, value of a country, effective weight of a world country (EW) expressed with definitions, tables, figures and mathematical functions. Also ideal political construction for a regional union and ideal political construction for the world countries' union are generally/specifically defined by considering these basics which are related with a world country and gave above.

Moreover, a general comparison is made in the fourth section of this work between the new administration systems and the past/present political/non-political systems in the world to express the differences, common points, new defined values, and others.

In the fifth section, applications and realization of the new methods and new theories are expressed. With this respect, new political constructions proposed for different party systems and for different federation systems in the world respectively. Some applications or re-constructions defined for all world countries due to four Case A to Case D theories and related 23 main methods (Ramiz, March 2016). General and specific evaluation of this work, some new perspectives, and some results about this work are given in the conclusion section.

Each of the letters, words, sentences, tables, figures, definitions, comparison, etc. within this article are considered by the author specifically, and most of them indicates some real life experienced subjects.

Some of the references are given in the other work (Ramiz, March 2016), and they are considered for the general synthesis where some of the results of this synthesis also given here in this work. Some other references are given here at the last section as additional sources to guide the people to understand the meaning of the some words, definitions used here, and for making comparison easily between the past, present works and the new theories, mew methods, new administrations systems defined here.

\section{New Methods and Theories for Political/Non-Political Administration Systems}

Following new theories and methods are defined to solve general and specific problems about persons, groups, communities, territories, states, countries in the world. There are four case theories (Ramiz, March 2016), which consists methods for "re-construction, and/or separation, and/or establishment" in/of a country or a union principally, for country based systems. In more specific manner, author defined constructional and complementary theories, ideologies, philosophies, sciences below for these case theories, and/or to supply the basics for the related processes to realize political/non-political administration systems.

Case A Theory: It is defined to solve problems in one country (for more than one group, community, territory in a country). It includes following five possible methods basically: (1) reconstruction of the country under the same country name; (2) separation of country to suitable different territories conditionally and then unification of the territories under new-upper re-constructed "same" country structure (Country Union); (3) separation of country to suitable different countries conditionally and then unification of the countries under 
"other" new upper re-constructed countries' union structure; (4) re-construction from federal territories of the country to countries' union; and (5) convert (re-construction) from monarch to country based hybrid-monarch.

Case B Theory: It is defined to solve problems between two countries, or two states, or two communities. It includes following six possible methods basically: (1) re-construction from united states to countries' union; (2) re-construction from confederation to countries' union; (3) re-construction from united federation to countries' union; (4) new establishment of a countries' union, which is base on some principles, conditions, sense of justice between any of these two sides; (5) separation of countries (or communities, states) to suitable different countries "conditionally" and then unification of the countries under "other" new upper re-constructed countries' union structure; and (6) separation of countries (or communities, states) to suitable different countries, and then unification of each country with other countries under "other" new upper re-constructed countries' union structure.

Case C Theory: It is defined to solve problems between more than two countries, or states, or communities, or kingdoms. It includes following nine possible methods basically: (1) convert (re-construction) from present united states to regional countries' union; (2) convert (re-construction) from present federation states to regional countries' union; (3) convert (re-construction) from present confederation states to regional countries' union; (4) convert (re-construction) from present united Kingdom to regional countries' union; (5) unification of countries to make new construction of regional countries' union; (6) unification of communities to re-construct regional countries' union; (7) convert (re-construction) from present union to regional countries' union; (8) Hybrid unification of countries, country unions, countries' unions, regional countries unions to make new regional countries' union; and (9) re-construction from present autonomous territories, regions, communities of the country to regional countries' union.

Case D Theory: It is defined to solve problems between any two or more sides. It includes the following three possible methods basically: (1) unification of sides (Category-A, Category-B, Category-C, Category-D, Category-E, Category-F) (Ramiz, March 2016) under one framework to establish new world countries' union; (2) convert (re-construct) from "present worldwide organization" to new world countries' union; (3) unification of sides (see six categories of Side theory, Ramiz, March 2016) under one framework to establish new world countries' union, and integration of the present worldwide organization to this new system.

Constructional and/or Complementary Theories, Ideologies, Philosophies, Sciences: Author considered following perspectives as constructional and/or complementary references for new administration systems, together and separately (in alphabetic order): (1) Country presidency system theory; (2) Effective weight (as theory, as science, as philosophy); (3) Ideal political construction (as theory, as ideology, as politics, as philosophy, as religious, as science); (4) Organization (as theory); (5) Progressive religion (as theory, as philosophy, as religious); (6) R-Administration (as theory, as science, as philosophy, as social, as politics, as ideology, as religious); (7) R-Administration System (as theory, as philosophy, as politics, as non-political, as ideology, as science); (8) R-Agreement (as theory, as philosophy, as ideology, as politics, as social, as commercial, as religious, as lawful); (9) R-Basic senses (as theory, as science, as philosophy, as justice, as constructional); (10) R-Centrism (as theory, as ideology, as politics, as philosophy, as science, as religious, as constructional); (11) R-Continuity/Sustainability theory (see dimensions); (12) R-democracy (as theory, as ideology, as philosophy, as science, as politics); (13) R-ethnic origin (as theory, as ideology, as science, as religious); (14) R-Hybrid (as theory, as science, as ideology, as philosophy, as politics, as social); (15) R-Ideology; (16) R-Information (as theory, as science, as philosophy, as religious, as ideology); (17) 
R-Integration (as theory, as ideology, as science, as philosophy, as social); (18) R-Interaction (as theory, as ideology, as social, as philosophy, as science, as religious, as politics); (19) R-Party system theory; (20) R-Philosophy; (21) R-Possibility (as theory, as science, as philosophy); (22) R-Priority (as theory, as philosophy, as ideology, as religious, as commercial, as security, as social); (23) R-Progression (as theory, as ideology, as philosophy, as science, as social, as political, as non-political) (Ramiz, 2015; Ramiz, March 2016); (24) R-Religion (as theory of religion, as ideology, as philosophy of religion); (25) R-Science (as theory, as philosophy, as science); (26) R-Security (as theory, as military, as ideology, as philosophy, as social); (27) R-Sense of justice (as theory, as science, as ideology, as philosophy, as religious, as law, as justice, as judgment, others-see dimensions); (28) R-Sensitivity (as theory, as science, as philosophy, as ideology, as religious); (29) R-Separation (as theory, as ideology, as politics, as science, as philosophy, as social, as lawful); (30) R-Side (as theory, as ideology, as politics, as philosophy, as science, as lawful); (31) R-Stability (as theory, as ideology, as politics, as science, as philosophy, as religious); (32) R-Supply/demand (as theory, as commercial, as science, as philosophy, as religious, as ideology); (33) R-Synthesis Theory; (34) R-System (as theory, as science, as philosophy, as ideology, as religious, as politics); (35) System administration (as theory, as ideology, as philosophy, as science, as religious); (36) R-Transformation (as theory, as science, as philosophy, as ideology, as religious); (37) R-Uniqueness (as theory, as ideology, as science, as philosophy, as religious); (38) R-Union (as theory, as social, as ideology, as science, as philosophy, as politics, as religious); (39) R-Values (as theory, as monetary, as ideology, as science, as philosophy, as religious, as social); and (40) others.

Although some/most/all of them are defined as theory, as ideology, as philosophy, and/or as a science, there are different dimensions related with these perspectives and are expressed more specifically in other work. Good and/or correct perspective that must be behind administration(s), are generally/specifically explained with comparative 99(+) perspectives in other work (Ramiz, March 2016), where they are considered as comparative elements for the definition of the above 39(+) perspectives.

Some of these theories, ideologies, are given in other work (Ramiz, 2015; Ramiz, January 2016; Ramiz, March 2016). Here "R-abcde...xyz" are used to express that they are considered by the author and they are new defined, or re-constructed from the past/present one, or modified, or used as it is same with the past/present one, or arranged due to all 21 dimensions of the synthesis (Ramiz, March 2016), and due to 27(+) inevitable result cases of the synthesis in general manner.

\section{New Administration Systems for the World Countries (Categories of Administration Systems)}

Here, four general case theories and 23 main methods given before are considered (Ramiz, March 2016), and the following new five possible categories are defined for administration systems to solve the general and specific problems. All of the administration systems are defined as country based. Some of these administration systems can be establish by re-construction of the old systems (Political systems, 2015) in a world country, while some other present country systems need to change, some other ones need to be re-constructed due to the 27(+) inevitable results of the synthesis given in this work and in other work (Ramiz, March 2016). In simple manner, these new administration systems, their sub blocs, and related system administrations, and their sub blocs, which are defined together with these systems, solves the following subjects: (a) some/most missing subjects in the present country systems; (b) some/most "bad and/or incorrect" parts of the present systems; (c) some/most conflicts in the present systems; and (d) some/most disputes in the present systems, and others. With 
this respect, the new defined administration systems are "good and/or correct" for each world countries. It is proposed by the author to make all of these administration systems as "good and correct" in the next step.

\section{General Political Administration System for a World Country}

The author defined "A Continuable Political Administration System for a World Country" before (Ramiz, September 2015; Ramiz, January 2016) to show the main important parts and subjects necessary for a world country to have continuable administration system in that country.

Within that system, there is a bloc named as "political administration" and given as part of the continuable political administration system for a world country. That political administration is expressed here as governmental/presidency related politic power organization. That power organization is defined together with the general political administration system for a world country (see Figure 1). This system is proposed to organize the communication between the political administration and other governmental/non-governmental units, and also for the communication between each bloc, and/or inside each bloc of the system. Each bloc generally defined below (see Figure 1), however their specific responsibilities defined in other work. Exception is the "system administration" part where its content, responsibilities, relation with some other blocs and administration systems are defined with more details in the following section of this work.

This political administration system is defined for most of the present federation states (federation, 2016) or world countries (Case-A: Method-A1) by considering governmental/non-governmental sides in the country.

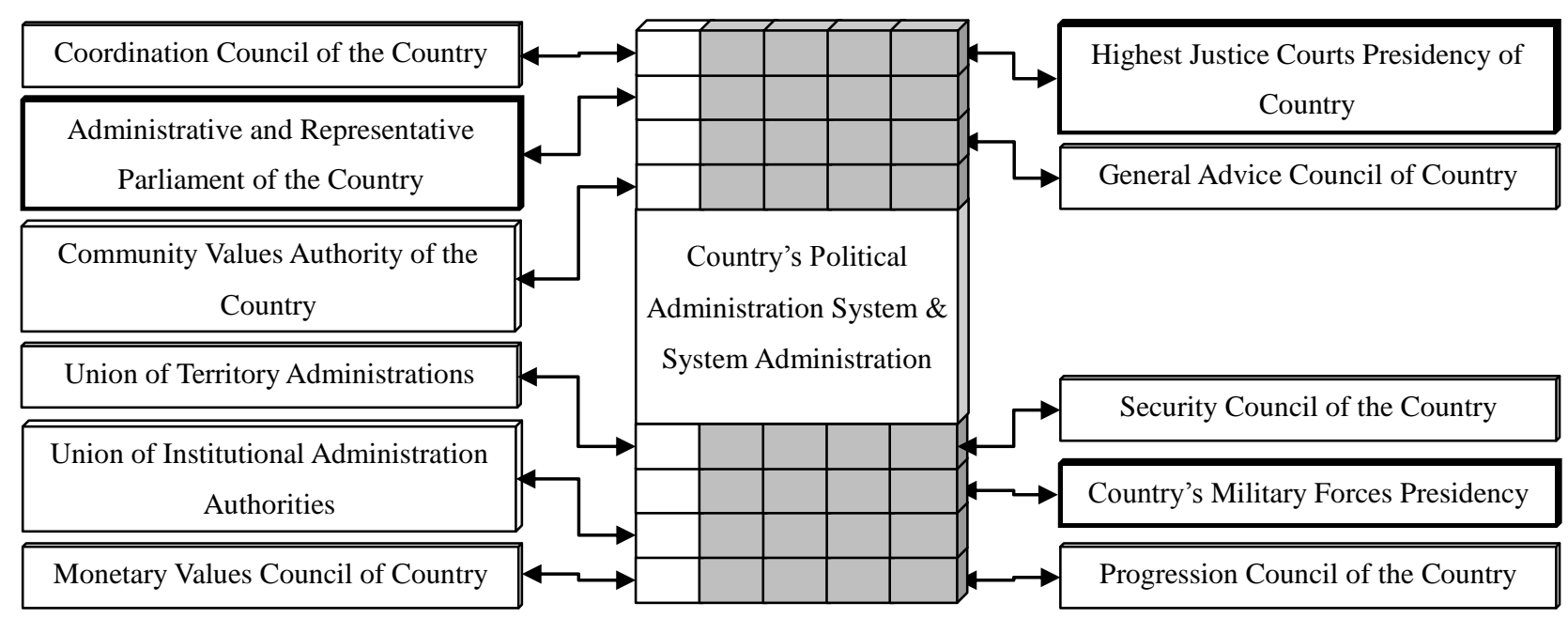

Figure 1. General political administration system for a World Country.

General specification of each bloc of the system gave below (in alphabetic order): (1) Administrative and Representative Parliament of Country: Includes elected/appointed persons, proposed to represent community, proposed to represent five to five structural groups in country, proposed to be constructed from high level educated people as possible as, and not among the possible bad and/or incorrect people; (2) Community Values Authority of Country; related with the community values (defined in other work); (3) Coordination Council of Country; proposed for 37 subjects of services, proposed for 11 blocs of the system and for main bloc; (4) General Advice Council of Country; proposed for 37 subjects of services, proposed for 11 blocs of the system; (5) Highest Justice Courts Presidency of Country (defined in other work); (6) Country's Military Forces Presidency (defined in other work); (7) Monetary Values Council of Country (defined in other work); (8) 
Progression Council of Country, Proposed for scientific studies about 37 subjects of services; (9) Security Council of Country (defined in other work); (10) Union of Institutional Administration Authorities, proposed for 37 subjects of services, and (11) Union of Territory Administrations (defined in other work). Each bloc includes presidency, council, committees, associations and R-autonomous construction.

\section{General Political Administration System for a Country Union}

To solve the general and specific problems inside some of the world countries, author considered Case-A (Method-A2) (Ramiz, March 2016) and defined the General Political Administration System for a Country with the new name of "Country Union" in Figure 2 below. Each bloc generally defined below, however their specific responsibilities defined in other work. Exception is the "system administration" part where its content, responsibilities, relation with some other blocs and administration systems are defined with more details in the following section of this work.

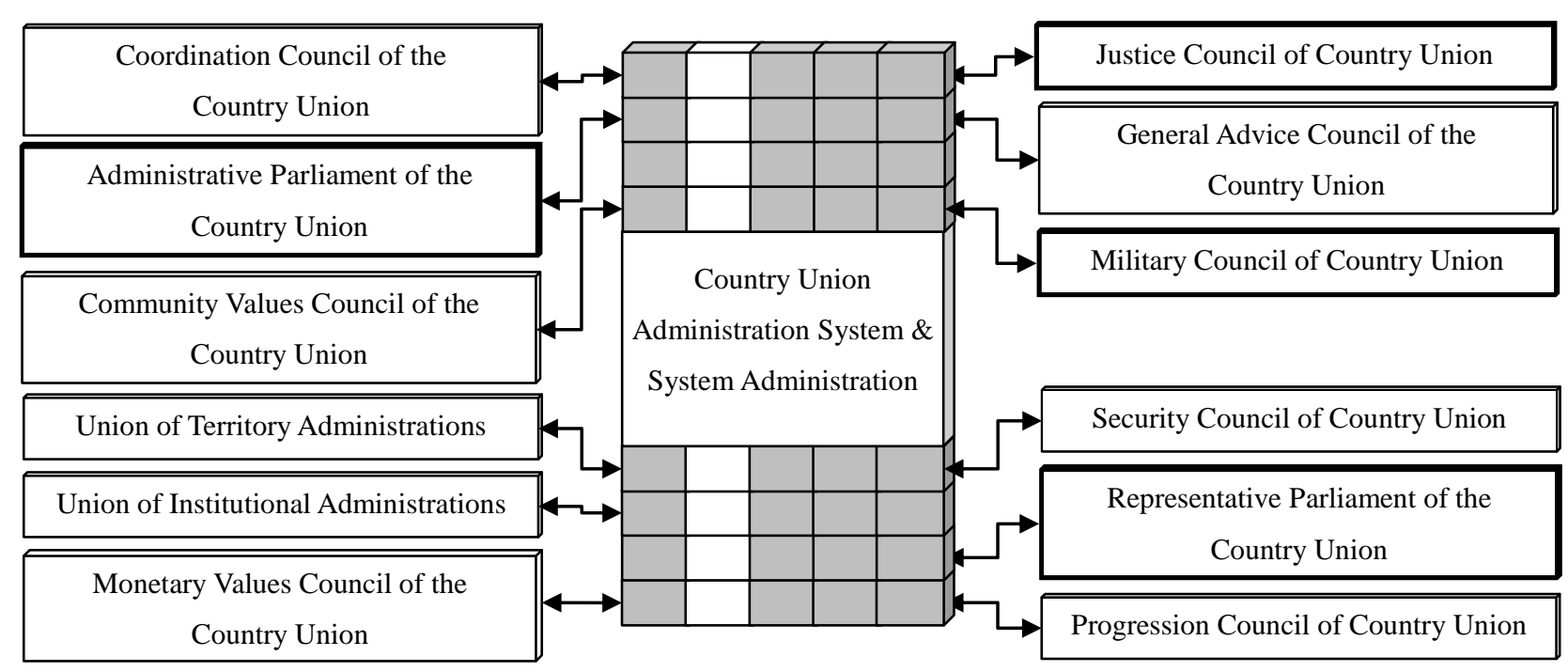

Figure 2. General political administration system of a Country Union.

General specification of each bloc of the system gave below (in alphabetic order): (1) Administrative Parliament of the Country Union: high level administration of communities, territories. Includes elected/appointed persons, proposed to represent communities, proposed to represent 5 to 5 structural groups in country, proposed to be constructed from high level educated people as possible as, and not among the possible bad and/or incorrect people; (2) Community Values Council of Country Union (defined in other work); (3) Coordination Council of Country Union; proposed for 37 subjects of services (Ramiz, 2015; Ramiz, 2016), proposed for 12 blocs of the system; (4) General Advice Council of Country Union; proposed for 37 subjects of services, proposed for 12 blocs of the system; (5) Justice Council of Country Union (defined in other work); (6) Military Council of Country Union (defined in other work); (7) Monetary Values Council of Country Union (defined in other work); (8) Progression Council of Country Union (defined for scientific studies about 37 subjects of services); (9) Representative Parliament of Country Union, high level representation of communities, territories. It includes elected/appointed persons, proposed to represent all communities, territories, proposed to represent 5 to 5 structural groups in country, proposed to be constructed from good level educated people as possible as, and not among the possible bad and/or incorrect people; (10) Security Council of Country Union (defined in other work); (11) Union of Institutional Administrations; proposed for 37 subjects of services; (12) 
Union of Territory Administrations (defined in other work). Each bloc includes presidency, council, committees, associations and R-autonomous construction.

\section{General Political Administration System for a Countries' Union}

It is considered to solve the general and specific problems of two communities, territories or two countries, with this union system. This union system is defined in Figure 3 below for some world countries due to Case-A (Method-A4), Case-B (Method-B1, Method-B2, Method-B3, Method-B4) theories and methods (Ramiz, March 2016), and such union system is named as countries'union due to the related union theory.

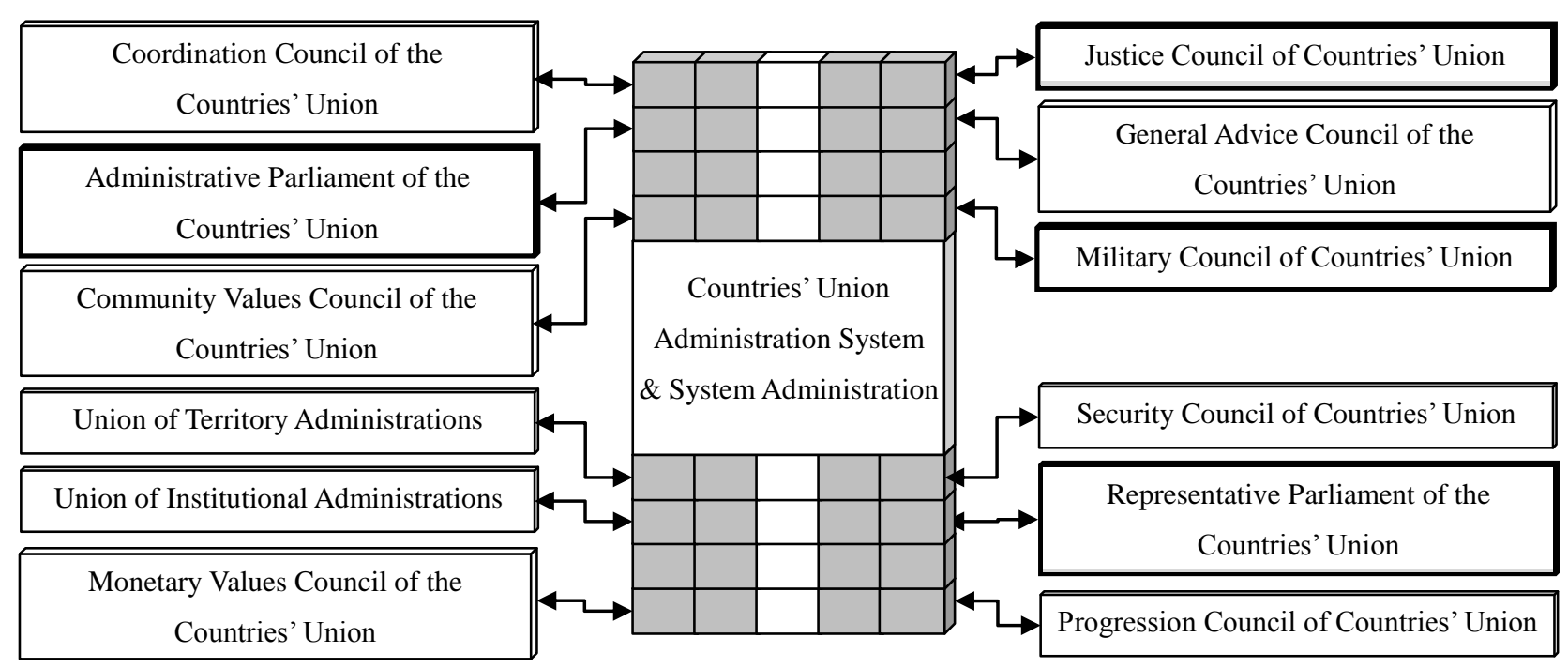

Figure 3. General political administration system of a countries' union.

Each country, which is a part of the countries' union, is proposed to have "a continuable political administration system" (Ramiz, 2015; Ramiz, January 2016), also a general political administration system (see Figure 1) and its related system administration (see Figure 6). General specifications of each bloc of the system in Figure 3 (in alphabetic order): (1) Administrative Parliament of the Countries' Union: high level representation of two states, or two countries. This is partly explained in the system administration section (see Figure 6) and other tables below. This bloc includes elected/appointed persons, proposed to represent five to five structural groups in each country, proposed to be constructed from high level educated people as possible as, and not among the possible bad and/or incorrect people; (2) Community Values Council of Countries' Union (defined in other work); (3) Coordination Council of Countries' Union; proposed for 37 subjects of services (Ramiz, 2015), proposed for 12 blocs of the system; (4) General Advice Council of Countries' Union; proposed for 37 subjects of services, proposed for 12 blocs of the system; (5) Justice Council of Countries' Union (defined in other work); (6) Military Council of Countries' Union (defined in other work); (7) Monetary Values Council of Countries' Union (defined in other work); (8) Progression Council of Countries' Union, proposed for scientific studies about 37 subjects of services; (9) Representative Parliament of Countries' Union, partly given in the system administration part (see Figure 6) below. It includes high level representation of the countries. It includes elected/appointed persons, proposed to represent all communities/territories in the two countries, proposed to represent five to five structural groups in each country, proposed to be constructed from good level educated people as possible as, and not among the possible bad and/or incorrect people (defined in other work); (10) Security Council of Countries' Union (defined in other work); (11) Union of Institutional 
Administrations; proposed for 37 subjects of services; and (12) Union of Territory Administrations (defined in other work). Each bloc includes presidency, council, committees, associations and R-autonomous construction.

\section{General Administration System for Regional Countries' Union}

It is considered to solve the general and specific problems of more than two communities, territories, states, countries, kingdoms, federations, or unions with this regional union system. This regional union system is defined in (Figure 4) below for some world states, countries, and others due to Case-A (Method-A3), Case-C (Method-C1, Method-C2, Method-C3, Method-C4, Method-C5, Method-C6, Method-C7, Method-C9) theories and methods (Ramiz, March 2016), and such regional union system is named as regional countries'union due to the related union theory.

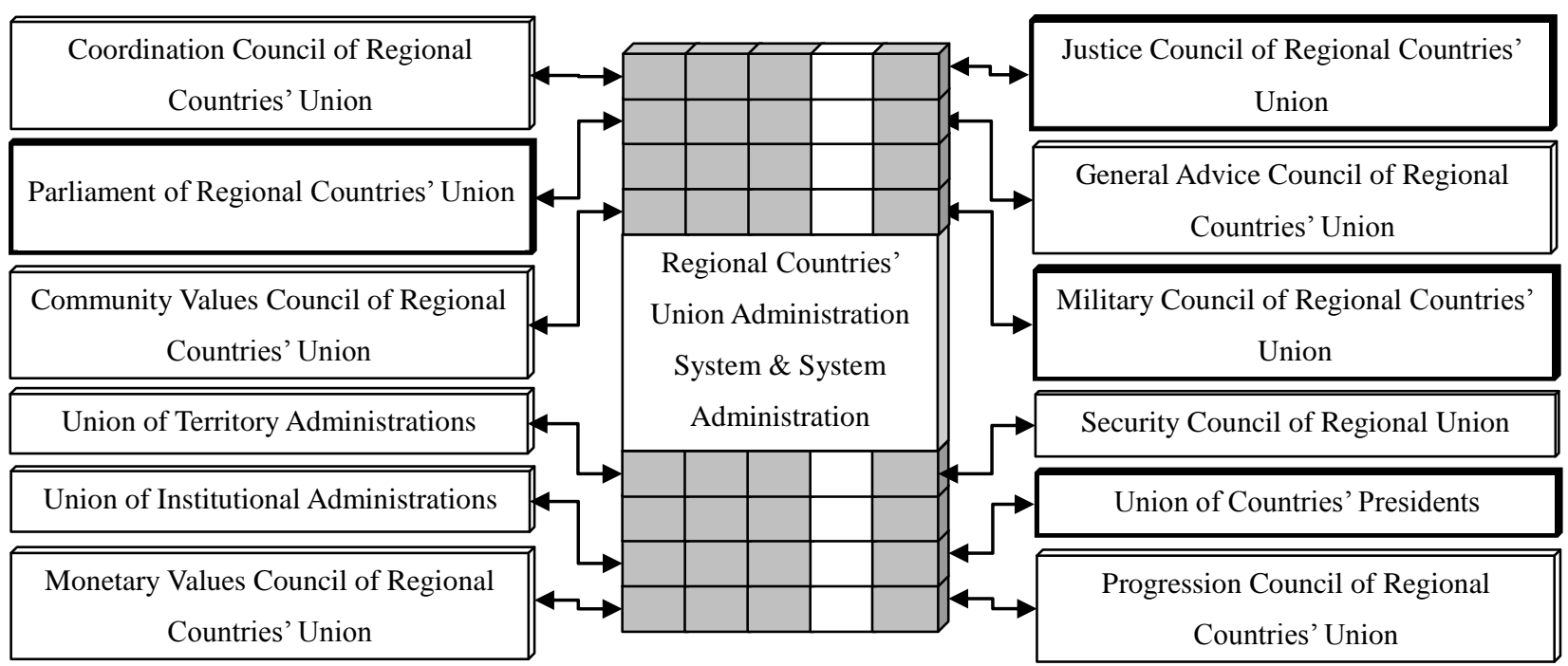

Figure 4. General administration system of a regional countries' union.

Each state* or country, which is part of the regional countries' union, is proposed to have "a continuable political administration system" (Ramiz, 2015; Ramiz, January 2016), also to have General Political Administration System for a Country (see Figure 1), and system administration (see Figure 6) for that country separately. General specifications of each bloc of the regional countries' union system, gave below (in alphabetic order): (1) Community Values Council of Regional Countries' Union; (defined in other work); (2) Coordination Council of Regional Countries' Union; proposed for 37 subjects of services (Ramiz, 2015), proposed for 12 blocs of the system; (3) General Advice Council of Regional Countries' Union, proposed for 37 subjects of services, proposed for 12 blocs of the system; (4) Justice Council of Regional Countries' Union (defined in other work); (5) Military Council of Regional Countries' Union (defined in other work); (6) Monetary Values Council of Regional Countries' Union (defined in other work); (7) Parliament of the Regional Countries' Union: high level representation of states, countries. It is defined generally together with the system's administration part (see Figure 6; Table 1 \& 2); (8) Progression Council of Regional Countries' Union, proposed for scientific studies about 37 subjects of services; (9) Security Council of Regional Countries' Union (defined in other work); (10) Union of Countries' President; formed by presidents of each state or country; (11) Union of Institutional Administrations, proposed for 37 subjects of services; (12) Union of Territory Administrations (defined in other work). Each bloc includes presidency, council, committees, associations and R-autonomous construction. 


\section{General Administration System for World Countries' Union}

It is considered to solve the general and specific problems of all humans, groups, communities, territories, states, countries, country union, countries' union, and/or regional countries union with this world union system. This world union system is defined in Figure 5 below for related sides due to Case-D (Method-D1, Method-D2, Method-D3) theories and methods (Ramiz, March 2016), and such world union system is named as "world countries'union" due to the related union theory.

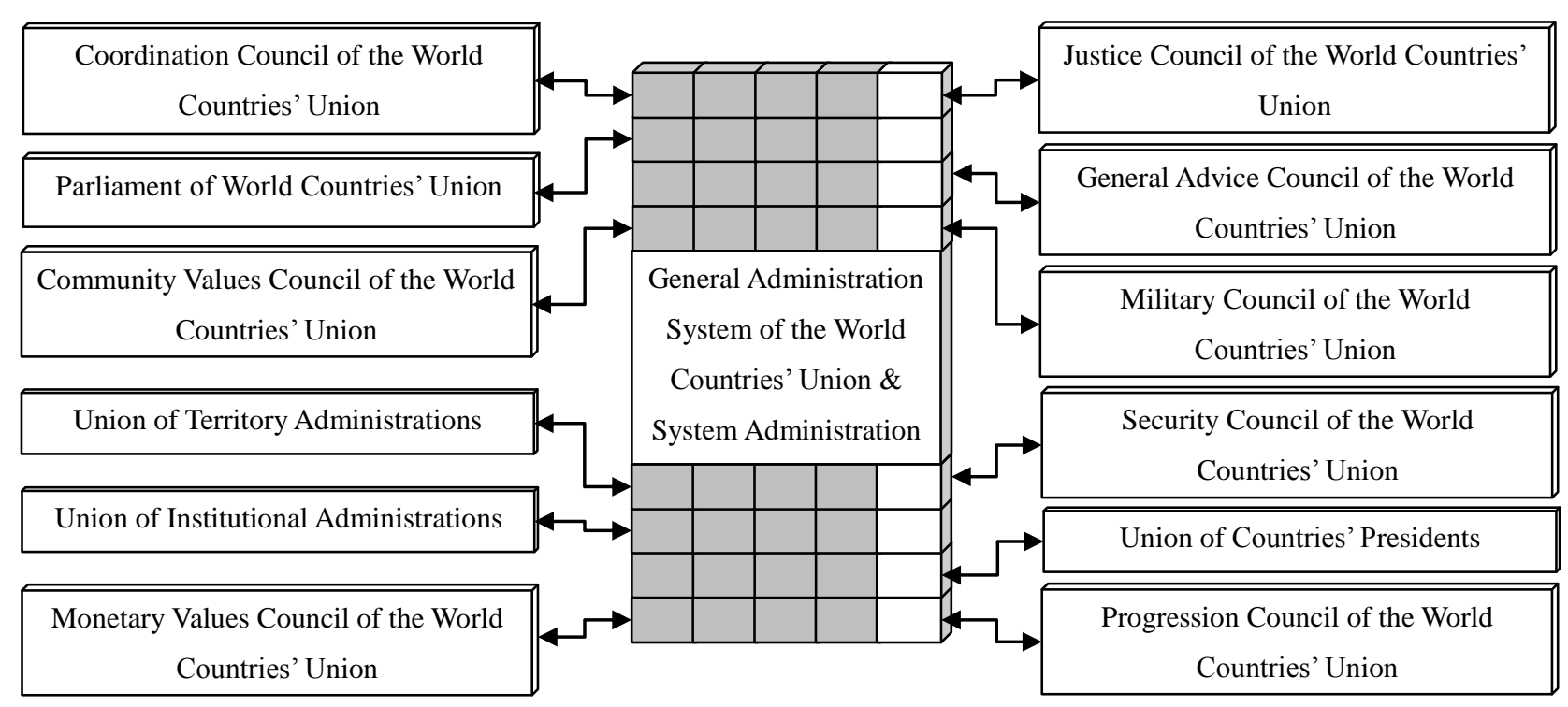

Figure 5. General administration system of the world countries' union.

General specifications of each bloc of the world countries' union system gave below (in alphabetic order): (1) Community Values Council of the World Countries Union (defined in other work); (2) Coordination Council of the World Countries' Union; proposed for 37 subjects of services (Ramiz, 2016 March), proposed for 12 blocs, proposed for each world country and sub countries; (3) General Advice Council of the World Countries' Union; proposed for 37 subjects of services, proposed for 12 blocs, proposed for each world country and sub countries; (4) Justice Council of the World Countries' Union (defined in other work); (5) Military Council of the World Countries' Union (defined in other work); (6) Monetary Values Council of the World Countries' Union (defined in other work); (7) Parliament of the world countries' union, high level representation of 200 countries (+) and each sub countries (50 for USA, 5 for UK, 28 for India, 27 for China, 21 for Russia, etc.); (8) Progression Council of the World Countries' Union; Proposed for scientific studies about 37 subjects of services; (9) Security Council of the World Countries' Union (defined in other work); (10) Union of Countries' Presidents; representation of each world country by its president (200 countries (+) others), (11) Union of Institutional Administrations; proposed for 37 subjects of services; and (12) Union of Territory Administrations (defined in other work). Each bloc includes presidency, council, committees, associations and R-autonomous construction. It is important to note that, world countries' union is defined so that all Groups, Communities, Countries, Country Unions, Countries' Unions, Regional Countries' Unions are represented. General system administration of this world union gave in Figure 6. 


\section{System Administration for All Categories of Administration Systems}

Each of these five categories of administration systems defined above consists coordination, parliament, institution, justice, advice, security, progression about 37-subjects of services, also consists community values (religions, sects, traditions, historical values, ethnic origins, thought and senses), monetary values, military perspectives specifically. With this respect, there is general/specific "system administration" construction (see Figure 6) defined by the author for each of these five categories of administration systems, and for each of the $11 / 12$ sub blocs of these administration systems.

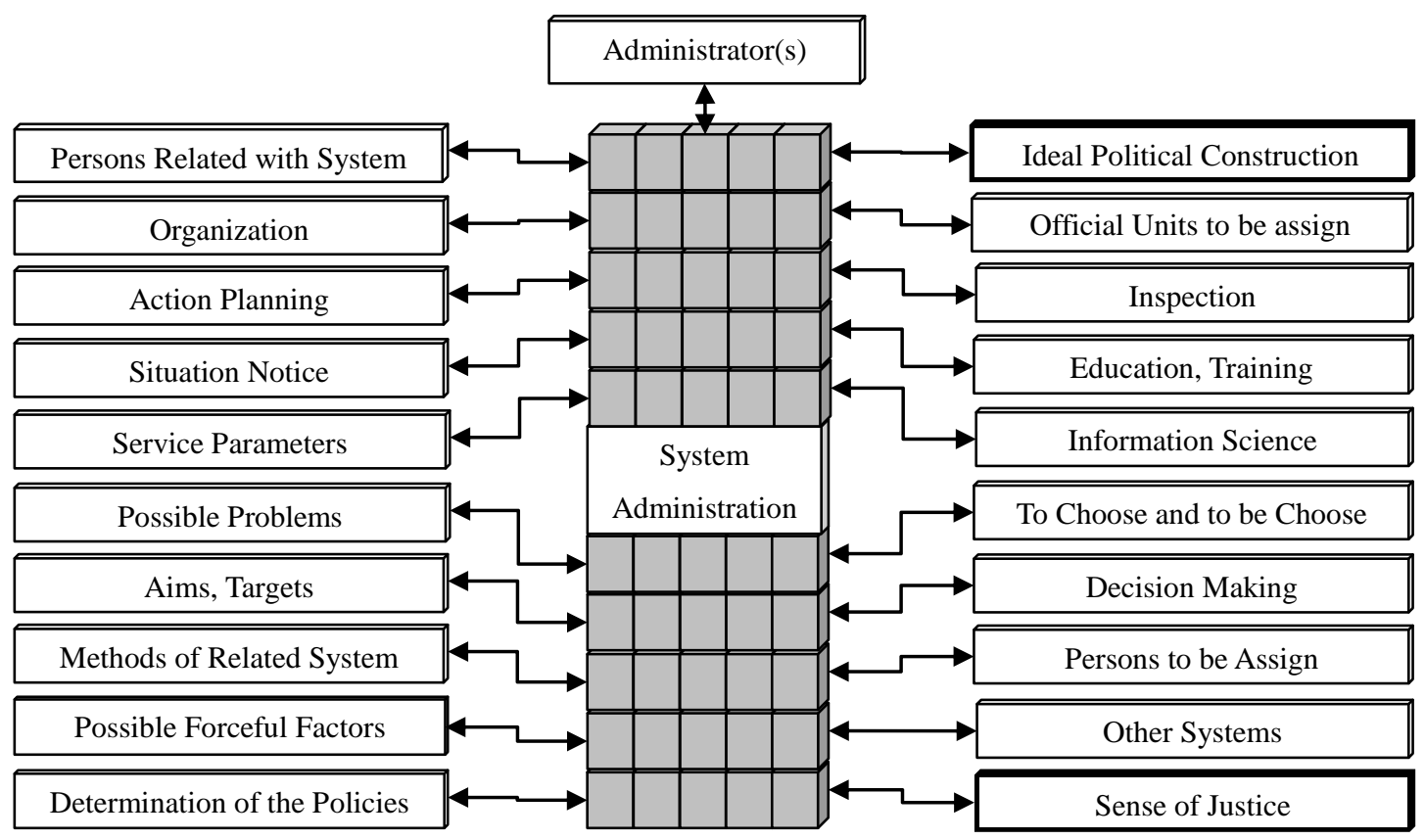

Figure 6. General construction for any type of system administration.

Here, this system administration is designed so that basics of this system administration are same/similar for all five categories of administration systems, and same/similar for all their related 12 sub blocs, and same/similar for all sub blocs of these 12 sub blocs. However, "some" parts are different due to the each sub bloc of each administration systems. Some general/specific explanations and/or definitions about some of the 21 blocs of this general construction (see Figure 6) are given below for any type of system administration. Some of the other blocs are defined in other works.

\section{Sense of Justice}

Sense of Justice, is defined partly in other work (Ramiz, 2016). However, here the author categorized the sense of justice, generally/specifically, for all types of administration systems and for the related system administrations to indicate the sensitivity considered in sense of justice, as follows (in alphabetic order): (1) sense of justice due to accessible information level: (a) necessary and sufficient information; (b) no information; (c) fully open information; (d) private information; (e) confidential information; and (f) R-Hybrid; (2) sense of justice due to accessibility period: (a) one time; (b) some times-when required; (c) every time-periodically; (d) every time-when required; (e) conditionally; (3) sense of justice due to administration (for all types of administration systems and related system administrations): (a) group administration; (b) company 
administration; (c) association/institution administration; (d) political party administration; (e) public administration; (f) local administration; (g) territory administration; (h) political administration; (i) country administration; (j) union administration; (k) world-wide administration; and (l) universal administration; (4) sense of justice due to applied methods: (a) by educating people; (b) by improving the justice system; (c) by making the system judicious; and (d) R-Hybrid; (5) sense of justice due to its applied founder: (a) due to his theory; (b) due to his ideology; (c) due to his philosophy; (d) due to his religion; (e) due to his science; (f) due to his principles; (g) due to his ethics; (h) due to his sense of justice; (i) due to his ideal political construction; (j) due to his synthesis; and (k) R-Hybrid; (6) sense of justice due to its applied time: (a) instantaneously; (b) simultaneously; (c) time divisioned; (d) independent from time; (e) time dependent, in short period, in mid period, in long period; and (f) R-Hybrid; (7) sense of justice due to basic senses: (a) 8-basic senses and subjects; (b) 8-basic senses and values; (c) 8-basic senses and levels; (d) 8-basic senses and comparison of singular and plural side; and (e) 8-basic senses and living forms; (8) sense of justice due to dimension; (9) sense of justice due to equivalence principle; (10) sense of justice due to formality: (a) official; (b) non-official; and (c) R-Hybrid; (11) sense of justice due to geographical structure considered: (a) territory based; (b) local; (c) country based; (d) regional; (e) transcontinental; (f) worldwide; and (g) universal/cosmos; (12) sense of justice due to interaction between sides: (a) internal; (b) common; (c) mutual; (13) sense of justice due to living forms: (a) bacteriums; (b) plants; (c) animals; (d) human being; (e) aliens; (f) other living creatures; (g) God(s); and (h) other highest living forms; (14) sense of justice due to number of sides considered: (a) one; (b) two; (c) three or more; (d) some; (e) most; and (f) all; (15) sense of justice due to perspective: (a) academic; (b) commercial; (c) democratic; (d) ethnic; (e) financial; (f) ideological; (g) lawful; (h) military; (i) national; (j) philosophical; (k) political; (l) religious; (m) scientific; (n) social; and (o) R-Hybrid; (16) sense of justice due to politics: (a) political; (b) non-political; and (c) R-Hybrid; (17) sense of justice due to priority; (18) sense of justice due to size, content and sensitivity of subject: (a) micro; (b) functional; and (c) macro; (19) sense of justice due to subjects: 37 subjects of services; (20) sense of justice due to way of accessibility: (a) singular accessible; (b) multiple accessible; and (c) R-Hybrid accessible; (21) sense of justice due to validity period: (a) for short period; (b) for mid period; and (c) for long period,

With this respect, if there is only one side, there will be internal sense of justice, and due to the sensitivity micro, functional and macro sense of justice. If there are two or more sides, there will be all of the internal, common, mutual sense of justice considered together with the all three micro, functional, macro sense of justices for each internal, common and mutual interaction. Author named all these categories and sub cases as R-sense of justice, which includes ideological, philosophical, scientific, religious and R-Hybrid perspective simultaneously. Some examples gave about the evaluation of the sense of justice for different subjects, in this work, and in the other articles (Ramiz, September 2015; Ramiz, January 2016; Ramiz, March 2016). More general/specific explanations are given in other works.

\section{Continuity/Sustainability}

Continuity (sustainability), is defined partly in other work (Ramiz, 2016). However, here it is categorized, generally/specifically, for all types of administration systems and for the related system administrations, and due to its basic perspectives included as follows (in alphabetic order): (1) continuity due to administration; (2) continuity due to applied methods: (a) by educating people; (b) by improving the system(s); (c) by applying sense of justice; (d) by protecting good or correct ones; and (e) R-Hybrid (of first four methods); (3) continuity 
due to ideology; (4) continuity due to information; (5) continuity due to basic senses; (6) continuity due to dimension; (7) continuity due to formality: (a) official; (b) non-official; and (c) R-Hybrid; (8) continuity due to geographical structure considered: (a) territory based; (b) local; (c) country based; (d) regional; (e) transcontinental; (f) worldwide; and (g) R-universal; (9) continuity due to living forms; (10) continuity due to number and/or size; (11) continuity due to philosophy; (12) continuity due to politics: (a) political; (b) non-political; (c) R-Hybrid; (13) Continuity due to religion; (14) continuity due to science; (15) continuity due to sense of justice; (16) continuity due to sensitivity; (17) continuity due to system; (18) continuity due to subjects of services; 37 subjects of services; (19) continuity due to time; (20) continuity due to validity period: (a) for short period; (b) for mid period; (c) for long period; and (d) infinite; and (21) continuity due to R-values.

The author named all these categories and sub cases as R-Continuity, which includes ideological, philosophical, scientific, religious, and hybrid perspective simultaneously.

\section{Types of System Administrations}

The types of system administrations are defined in Table 2 for each of the five categories of administration systems defined above.

Table 2

Types of System Administrations

\begin{tabular}{|l|l|l|l|}
\hline $\begin{array}{l}\text { Type of Administration } \\
\text { System }\end{array}$ & Type of System Administration & Administrator(s) & $\begin{array}{l}\text { Number of Administrative } \\
\text { Person }\end{array}$ \\
\hline Country & Country Presidency System & President of Country & $1+$ \\
\hline Country Union & Country Union Presidency System & President of Country Union & $1+$ \\
\hline Countries' Union & Countries' Union Presidency System & President of Countries' Union & $1+12$ (one for each bloc) \\
\hline Regional Countries' Union & $\begin{array}{l}\text { Regional Countries' Union (RCU) } \\
\text { Presidency System }\end{array}$ & $\begin{array}{l}\text { A. Administration Council + } \\
\text { B. President of RCU }\end{array}$ & $1+12$ (one for each bloc) \\
\hline World Countries' Union & $\begin{array}{l}\text { World Countries' Union Presidency } \\
\text { System }\end{array}$ & Administration Council & 12 (one for each bloc) \\
\hline
\end{tabular}

\section{New Presidency System for a World Country}

The author defined "some" units of the Country Presidency System (see Table 2) below. Here, characteristics features of this presidency system gave first (see Table 3), then fundamental and respresentative duties related with each of the responsible and units gave generally/specifically (see Table 4). These tables also shows the relations with other units in the system.

Table 3

Characteristic Features of the Country Presidency

(For the Country Based Political Administration System)

\begin{tabular}{|c|l|l|l|l|l|}
\hline 1st President & 2nd President & 3rd President & 4th President & 5th President & 6th President \\
\hline $\begin{array}{c}\text { Elected/selected } \\
\text { President of Country } \\
\text { and/or } \\
\begin{array}{c}\text { Representative of } \\
\text { Royal Family } \\
\text { and/or }\end{array} \\
\begin{array}{c}\text { Elected/Selected } \\
\text { Monarch }\end{array}\end{array}$ & $\begin{array}{c}\text { Elected, selected, } \\
\text { advised member of } \\
\text { Country Parliament }\end{array}$ & $\begin{array}{c}\text { Elected, selected, } \\
\text { advised member of } \\
\text { Country Parliament }\end{array}$ & $\begin{array}{c}\text { Elected, selected, } \\
\text { advised member of } \\
\text { Country Parliament }\end{array}$ & $\begin{array}{c}\text { Elected, selected, } \\
\text { advised member of } \\
\text { Country Parliament }\end{array}$ & $\begin{array}{c}\text { Elected, selected, } \\
\text { advised member of } \\
\text { Country Parliament }\end{array}$ \\
$\begin{array}{c}\text { Holding good degree } \\
\text { from University }\end{array}$ & $\begin{array}{c}\text { Holding good degree } \\
\text { from University }\end{array}$ & $\begin{array}{c}\text { Holding good degree } \\
\text { from University }\end{array}$ & $\begin{array}{c}\text { Holding good degree } \\
\text { from University }\end{array}$ & $\begin{array}{c}\text { Holding good degree } \\
\text { from University }\end{array}$ & $\begin{array}{c}\text { Holding good degree } \\
\text { from University }\end{array}$ \\
\hline
\end{tabular}


NEW ADMINISTRATION SYSTEMS FOR THE WORLD COUNTRIES AND SENSE OF JUSTICE 233

Table 4

Possible Fundamental and Representative Duties of the Country Presidency

(For the Country Based Political Administration System)

\begin{tabular}{|c|c|c|c|c|c|}
\hline 1st President & 2nd President & 3rd President & 4th President & 5th President & 6th President \\
\hline President of Country & $\begin{array}{l}\text { Head of the Country } \\
\text { National Parliament }\end{array}$ & $\begin{array}{l}\text { Head of the Country } \\
\text { Political } \\
\text { Government }\end{array}$ & $\begin{array}{l}\text { Responsible of the } \\
\text { Country's Territory } \\
\text { Administrations }\end{array}$ & $\begin{array}{l}\text { Responsible of the } \\
\text { Country's Provinces }\end{array}$ & $\begin{array}{l}\text { Responsible of the } \\
\text { Country's } \\
\text { Institutional } \\
\text { Administrations }\end{array}$ \\
\hline \multicolumn{6}{|c|}{ Representative of the country at Regional Countries' Union and/or Representative of the country at World Countries' Union } \\
\hline \multirow[t]{2}{*}{$\begin{array}{l}\text { Head of the } \\
\text { 2nd President, } \\
\text { 3rd President, } \\
\text { 4th President, } \\
\text { 5th President, } \\
\text { 6th President }\end{array}$} & $\begin{array}{l}\text { Head of the } \\
\text { parliamentarian } \\
\text { Committees; A2, } \\
\text { B2, C2, D2, E2, F2 }\end{array}$ & $\begin{array}{l}\text { Head of the } \\
\text { Deputies: } \\
\text { Deputy-A3 } \\
\text { Deputy-B3 } \\
\text { Deputy-C3 } \\
\text { Deputy-D3 } \\
\text { Deputy-E3 } \\
\end{array}$ & $\begin{array}{l}\text { Head of the } \\
\text { parliamentarian } \\
\text { Committees; A4, } \\
\text { B4, C4 }\end{array}$ & $\begin{array}{l}\text { Head of the } \\
\text { parliamentarian } \\
\text { Committee; A5 }\end{array}$ & $\begin{array}{l}\text { Head of the } \\
\text { parliamentarian } \\
\text { Committees; A6, } \\
\text { B6, C6 }\end{array}$ \\
\hline & $\begin{array}{l}\text { Committee-A2: } \\
\text { For 1st Presidency, } \\
\text { Committee-B2: } \\
\text { For 2nd Presidency } \\
\text { Committee-C2: } \\
\text { For 3rd Presidency } \\
\text { Committee-D2: } \\
\text { For 4th Presidency } \\
\text { Committee-E2: } \\
\text { For 5th Presidency, } \\
\text { Committee-F2: } \\
\text { For 6th Presidency, }\end{array}$ & $\begin{array}{l}\text { Head of the } \\
\text { Ministries: } \\
\text { Ministry-1 } \\
\text { Ministry-2 } \\
\text {. } \\
\text { - } \\
\text { Ministry-K }\end{array}$ & $\begin{array}{l}\text { Committee-A4: } \\
\text { For Country, } \\
\text { Committee-B4: } \\
\text { For Regional } \\
\text { Countries' Union, } \\
\text { Committee-C4: } \\
\text { For World } \\
\text { Countries' Union }\end{array}$ & $\begin{array}{l}\text { Committee-A5: } \\
\text { For Country, } \\
\text { Includes } \\
\text { Representatives of } \\
\text { each provinces in the } \\
\text { country }\end{array}$ & $\begin{array}{l}\text { Committee-A6: } \\
\text { For Country, } \\
\text { Committee-B6: } \\
\text { For Regional } \\
\text { Countries' Union, } \\
\text { Committee-C6: } \\
\text { For World } \\
\text { Countries' Union }\end{array}$ \\
\hline Others & Others & Others & Others & Others & Others \\
\hline
\end{tabular}

\section{Ideal Political Construction for a World Country}

Each of the community, territory, state, or country proposed to have ideal political construction as follows (see Table 5). Although some words are enough to explain the ideologies of each of these 5-structural groups or 25 sub-groups due to philosophical perspective given above, Table 5 is defined below to give more information about the content and results of the synthesis, which considers the groups and proposed ideologies connected to them (R-Ideology; Ramiz, 2015).

Table 5

Ideal Political Construction for a World Country (Groups and Their Good and/or Correct Ideologies)

\begin{tabular}{|c|c|c|c|c|}
\hline $\begin{array}{c}\text { 1. New Era Politic } \\
\text { Group }\end{array}$ & $\begin{array}{l}\text { 2. Progression of The } \\
\text { Country Politic Group }\end{array}$ & $\begin{array}{l}\text { 3. Unity of The Country } \\
\text { Politic Group }\end{array}$ & $\begin{array}{l}\text { 4. Values of The Country } \\
\text { Politic Group }\end{array}$ & $\begin{array}{l}\text { 5. Social Progression } \\
\text { Politic Group }\end{array}$ \\
\hline $\operatorname{Gr}(1,1) ; \mathrm{I}(1,1) ; \mathrm{New}$ & $\operatorname{Gr}(2,1) ; \mathrm{I}(2,1) ;$ New & $\operatorname{Gr}(3,1) ; \mathrm{I}(3,1) ;$ New & $\operatorname{Gr}(4,1)$ & \\
\hline $\operatorname{Gr}(1,2) ; \mathrm{I}(1,2) ; \mathrm{New}$ & $\operatorname{Gr}(2,2) ; \mathrm{I}(2,2) ;$ modified & $\operatorname{Gr}(3,2) ; \mathrm{I}(3,2) ;$ modified & $\operatorname{Gr}(4,2) ; \mathrm{I}(4,2) ;$ modifie & $\operatorname{Gr}(5,2) ; \mathrm{I}(5,2)$; modified \\
\hline $\operatorname{Gr}(1,3) ; \mathrm{I}(1,3)$; New & $\operatorname{Gr}(2,3) ; \mathrm{I}(2,3)$; modified & $\operatorname{Gr}(3,3) ; \mathrm{I}(3,3) ;$ modified & $\operatorname{Gr}(4,3) ; \mathrm{I}(4,3) ;$ modified & 3); I $(5,3)$; modified \\
\hline $\operatorname{Gr}(1,4) ; \mathrm{I}(1,4) ; \mathrm{New}$ & $\operatorname{Gr}(2,4) ; \mathrm{I}(2,4) ;$ modified & $\operatorname{Gr}(3,4) ; \mathrm{I}(3,4) ;$ modified & $\operatorname{Gr}(4,4)$ & $\operatorname{Gr}(5,4) ; \mathrm{I}(5,4)$; modified \\
\hline $\operatorname{Gr}(1,5) ; \mathrm{I}(1,5)$; New & $\operatorname{Gr}(2,5) ; \mathrm{I}(2,5)$; modified & $\operatorname{Gr}(3,5) ; \mathrm{I}(3,5)$; modified & $\operatorname{Gr}(4,5) ; \mathrm{I}(4,5)$; modified & $\operatorname{Gr}(5,5) ; \mathrm{I}(5,5)$; modified \\
\hline
\end{tabular}

Note. Here $\mathrm{Gr}(\mathrm{i}, \mathrm{j})$ denotes the number of the sub-group, and $\mathrm{I}(\mathrm{i}, \mathrm{j})$ denotes proposed Ideology of the sub-group.

Here, the good and/or correct ideologies of the each of the sub-group in Table 5 are defined as result of the synthesis, and based on the general perspective they must have for continuable/sustainable administration in the county or in any other types of union; I $(1,1)$ : R-Centrism (New Era), I(1, 2): New Era and Progression of the 
Country, I(1, 3): New Era and Unity of the Country, I(1, 4): New Era and Values of the Country, I(1, 5): New Era and Social Progression, I $(2,1)$ : Constructional Centrism-2 (Progression of the Country and New Era), I(2, 2): Progression of the Country, I(2, 3): Progression of the Country and Unity of the Country, I(2, 4): Progression of the Country and Values of the Country, $\mathrm{I}(2,5)$ : Progression of the Country and Social Progression, I(3,1): Constructional Centrism-3 (Unity of the country and New Era), I(3, 2): Unity of the Country and Progression of the Country, I(3, 3): Unity of the Country, I(3, 4): Unity of the Country and Values of the Country, I(3, 5): Unity of the Country and Social Progression, I(4, 1): Constructional Centrism-4 (Values of the Country and New Era), I(4, 2): Values of the Country and Progression of the Country, I(4, 3): Values of the Country and Unity of Country, I(4, 4): Values of the Country, I $(4,5)$ : Values of the Country and Social Progression, I(5, 1): Constructional Centrism-5 (Social Progression and New Era), I(5, 2): Social Progression and Progression of the Country, I(5, 3): Social Progression and Unity of Country, I(5, 4): Social Progression and Values of the Country, I $(5,5)$ : Social Progression. The "new" defined five political groups given in the first row and also in the first column in Table 5 refers the convergence points of 5 to $5(=25)$ sub politic groups. To explain this, there are different ways of synthesis that can be considered by person. Two ways of synthesis are given below (see Table 6).

Table 6

First Way of Synthesis for a Person

\begin{tabular}{|c|c|c|c|c|}
\hline Gr.1 & Gr.2 & Gr.3 & Gr.4 & Gr.5 \\
\hline$(1,1)$ & & & & \\
\hline$(1,2)$ & & & & $(5,2)$ \\
\hline$(1,3)$ & & & $(4,3)$ & $(5,3)$ \\
\hline$(1,4)$ & & $(3,4)$ & $(4,4)$ & $(5,4)$ \\
\hline$(1,5)$ & $(2,5)$ & $(3,5)$ & $(4,5)$ & $(5,5)$ \\
\hline
\end{tabular}

Second Way of Synthesis for a Person

\begin{tabular}{lllll}
\hline Gr.1 & Gr.2 & Gr.3 & Gr.4 & Gr.5 \\
\hline$(1,1)$ & \multirow{(2,1)}{*}{$(3,1)$} & $(4,1)$ & $(5,1)$ \\
$(1,2)$ & $\leftarrow(2,2)$ & $(3,2)$ & $(4,2)$ & $(5,2)$ \\
$(1,3)$ & $\leftarrow(2,3)$ & $(3,3)$ & $(4,3)$ & $(5,3)$ \\
$(1,4)$ & $\leftarrow(2,4)$ & $(3,4)$ & $(4,4)$ & $(5,4)$ \\
$(1,5)$ & $\leftarrow(2,5)$ & $(3,5)$ & $(4,5)$ & $(5,5)$ \\
\hline
\end{tabular}

Note. Here the arrows and their directions shows the proposed way of synthesis for each group in each column or row.

It is important to integrate all political/non-political groups into the ideal political construction of a world country to obtain continuability/sustainability in the system. Of course the method of integration is important as well. Although the ideal political construction includes "political" word, it reflects political thoughts of non-political groups as well, together with the "ideal" and "construction" perspectives. This includes the above statement, which expresses the fact that each discipline includes directly and/or indirectly the other perspectives because of the interaction with other disciplines. So some people must notice the difference between this new perspective and the perspective which suggest to form politicized community. It is important for the people to have "necessary and/or sufficient" information about these perspectives. This is also important part of creating "information society/community". These subjects are explained with figures and definitions in other work (Ramiz, March 2016). However, there are some bad examples in Europe, where some people do not care (nearly $50 \%$ ) about politics in the elections of some countries. However there are some good/bad situations in some other world countries where every people in the country involved with politics and establish many political parties there. With this respect, for both cases, it is good and/or correct to integrate all people in these countries to the ideal political construction, and while they are trying to do something through political way, guide them not to create other problems, confuse, conflicts, dispute, etc. in the system.

Way of integration of the some past and present politic/non-politic groups into the ideal political 
construction is defined with the Table 7 below by considering one ethnic origin as an example in one world country. Some of the integrations of some specific persons and groups are defined in other work (Ramiz, 2015; Ramiz, January 2016).

Table 7

Integration of the Past and Present Political/Non-Political Groups Into the Ideal Political Construction (An Example for One Ethnic Origin in One World Country)

\begin{tabular}{|c|c|c|c|c|}
\hline $\begin{array}{l}\text { 1. New Era Politic } \\
\text { Group }\end{array}$ & $\begin{array}{l}\text { 2. Progression of The } \\
\text { Country Politic Group }\end{array}$ & $\begin{array}{l}\text { 3. Unity of The Country } \\
\text { Politic Group }\end{array}$ & $\begin{array}{l}\text { 4. Values of The Country } \\
\text { Politic Group }\end{array}$ & $\begin{array}{l}\text { 5. Social Progression } \\
\text { Politic Group }\end{array}$ \\
\hline $\begin{array}{l}1.1 \quad(\mathrm{NEW}) \\
\text { \#R-Centrism } \\
\text { \#R-Progressive } \\
\text { \#R-Democracy } \\
\text { \#I }(1,1)\end{array}$ & $\begin{array}{l}2.1(\mathrm{New}) \\
\text { \#Constructional } \\
\text { Centrism-2 } \\
\text { \#R-progressive } \\
\text { \#R-democracy } \\
\text { \#I }(2,1)\end{array}$ & $\begin{array}{l}\text { 3.1 (New) } \\
\text { \#Constructional } \\
\text { Centrism-3 } \\
\text { \#R-progressive } \\
\text { \#R-democracy } \\
\text { \#I }(3,1)\end{array}$ & $\begin{array}{l}4.1 \text { (New) } \\
\text { \#Constructional } \\
\text { Centrism-4 } \\
\text { \#R-progressive } \\
\text { \#R-democracy } \\
\text { \#Religion** \#I }(4,1)\end{array}$ & $\begin{array}{l}5.1(\mathrm{New}) \\
\text { \#Constructional } \\
\text { Centrism-5 } \\
\text { \#R-progressive } \\
\text { \#R-democracy } \\
\text { \#I }(5,1)\end{array}$ \\
\hline $\begin{array}{l}1.2 \quad(\mathrm{New}) \\
\text { \#R-Democracy } \\
\text { \#R-Progressive } \\
\text { \#R-Monetarist } \\
\text { \#I }(1,2)\end{array}$ & $\begin{array}{l}2.2 \text { (modified) } \\
\text { \#liberals*, } \\
\text { \#monetarists-2* } \\
\text { \#other*** }\end{array}$ & $\begin{array}{l}3.2 \text { (modified) } \\
\text { \#monetarists-3* } \\
\text { \#other*** }\end{array}$ & $\begin{array}{l}4.2 \text { (modified) } \\
\text { \#monetarists- } 4 * \\
\text { \#liberal Conservatism* } \\
\text { \#other*** }\end{array}$ & $\begin{array}{l}5.2 \text { (modified) } \\
\text { \#communists* } \\
\text { \#monetarists-5* } \\
\text { \#atheists* } \\
\text { \#other*** }\end{array}$ \\
\hline $\begin{array}{l}1.3 \quad \text { (New) } \\
\text { \#R-Unity } \\
\text { \#R-National } \\
\text { \#R-Democracy } \\
\text { \#R-Progressive } \\
\text { \#I }(1,3)\end{array}$ & $\begin{array}{l}2.3 \text { (modified) } \\
\text { \#other*** }\end{array}$ & $\begin{array}{l}3.3 \text { (modified) } \\
\text { \#nationalists* } \\
\text { \#radicalism-3 } \\
\text { \#other*** }\end{array}$ & $\begin{array}{l}4.3 \text { (modified) } \\
\text { \#religious nationalism* } \\
\text { \#other*** }\end{array}$ & $\begin{array}{l}5.3 \text { (modified) } \\
\text { \#other*** }\end{array}$ \\
\hline $\begin{array}{l}1.4 \quad(\mathrm{New}) \\
\text { \#Progressive } \\
\text { Religion** } \\
\text { \#R-Values } \\
\text { \#R-Democracy } \\
\text { \#R-Progressive } \\
\text { \#I }(1,4) \\
\end{array}$ & $\begin{array}{l}2.4 \text { (modified) } \\
\text { \#Christian democrats* } \\
\text { \#sect of a religion** } \\
\text { \#other*** }\end{array}$ & $\begin{array}{l}3.4 \text { (modified) } \\
\text { \#nationalist } \\
\text { conservatism* } \\
\text { \#cultural conservatism* } \\
\text { \#sect of a Religion** } \\
\text { \#other*** }\end{array}$ & $\begin{array}{l}4.4 \text { (modified) } \\
\text { \#conservatism* } \\
\text { \#radicalism-4 } \\
\text { \#sect of a religion } * * \\
\text { \#other*** }\end{array}$ & $\begin{array}{l}5.4 \text { (modified) } \\
\text { \#religious socialism* } \\
\text { \#other*** }\end{array}$ \\
\hline $\begin{array}{l}1.5 \text { (New) } \\
\text { \#R-Social } \\
\text { \#R-Democracy } \\
\text { \#R-Progressive } \\
\text { \#singers-1 } \\
\text { \#I }(1,5)\end{array}$ & $\begin{array}{l}2.5 \text { (modified) } \\
\text { \#social democracy-2* } \\
\text { \#environmentalist-2 } \\
\text { \#singers-2 } \\
\text { \#other*** }\end{array}$ & $\begin{array}{l}3.5 \text { (modified) } \\
\text { \#environmentalist-3 } \\
\text { \#singers-3 } \\
\text { \#other*** }\end{array}$ & $\begin{array}{l}4.5 \text { (modified) } \\
\text { \#social conservatism* } \\
\text { \#conservationist } \\
\text { environmentalist-4 } \\
\text { \#singers-4 } \\
\text { \#others*** }\end{array}$ & $\begin{array}{l}5.5 \text { (modified) } \\
\text { \#socialists* } \\
\text { \#green politics*, } \\
\text { \#environmentalist-5 } \\
\text { \#singers-5 } \\
\text { \#other*** }\end{array}$ \\
\hline
\end{tabular}

Notes. (*) some old defined dominant ideologies for a country. Some of their invariants are not mentioned; (**) some of the dominant religion groups. The other sub groups also includes a belief, but they are not mentioned here; (***) for other groups related with the subjects of services.

There are some new definitions in Table 7, where they are defined as result of the synthesis to characterize each new group ideology due to the dimensions of the synthesis given in the other work (Ramiz, March 2016). Some of these new definitions in Table 7 are simply given as (in alphabetic order); Constructional Centrism, Progressive Religion, R-Centrism, R-Democracy, R-Monetarist, R-National, R-Progressive, R-Social, R-Unity, R-Values. The author defined these new dimensions/values/perspectives by using different constructional methods: (1) due to ideal political construction distribution; (2) due to graphic bar levels; (3) due to relations with each of 37 subjects of services; (4) due to political/non-political progression figure (Ramiz, March 2016); (5) due to figure given with sense of justice (Ramiz, March 2016); (6) due to the relations between ideology, science and religion; (7) due to the definition of the word; (8) due to the (see Figure 7); (9) due to the old known political ideologies; (10) due to the method-(a) political construction by putting together the values 
(Ramiz, 2015); (11) due to the method-(c) political construction based on the new values (Ramiz, 2015); and (12) others.

Although ideal political construction is defined due to the 5 structural groups (Ramiz, 2015), it includes basically 5 to 5 sub groups, as it is given in Table 5 . In more specific manner there are (NoE x $5 \times 5$ ) sub groups (see Figure 7), or (NoE x 5 x 5 x SoS) sub groups proposed for each world country, where NoE denotes the number of the ethnic origin (Ethnic Groups, 2015; other), SoS denotes the 37 subjects of services (Ramiz, March 2016). With this respect, it is possible to show the integration of all of the politic groups, religious groups, ethnic groups, scientific groups, philosophical groups, ideological groups, business groups, R-Hybrid group(s) to the new construction system in one figure as it is given in Figure 7 below. Figure 7 also defines the new centers that are country specific and/or world specific. The general diagram for the world is defined in following sections separately.

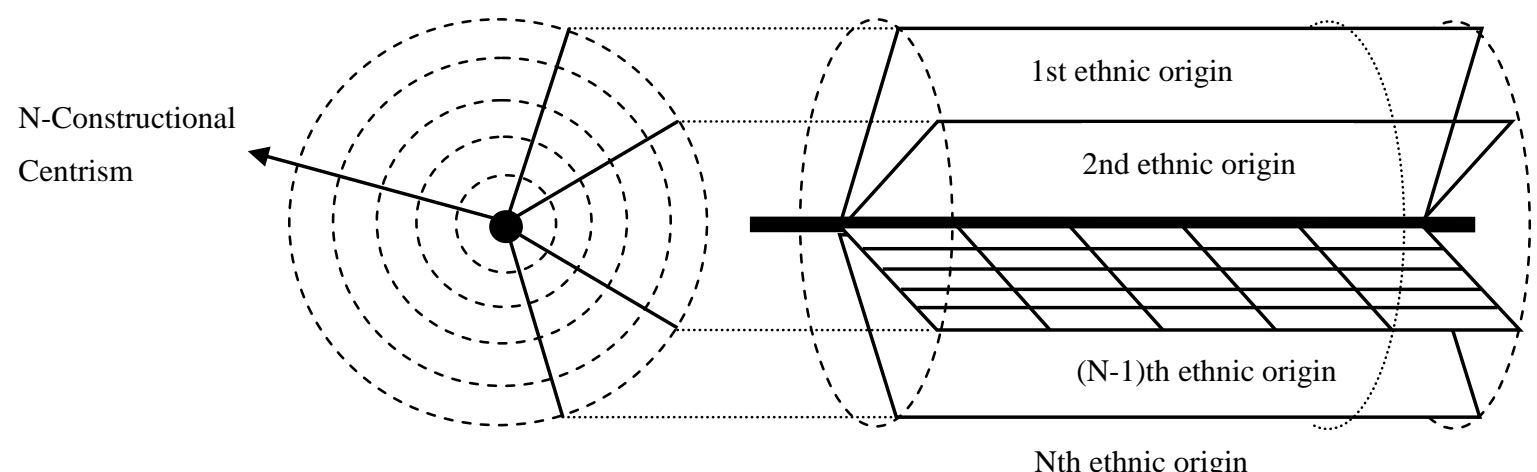

Figure 7. Structural groups in a world country ( $N \times 5 \times 5$ groups).

It is also important to define "ethnic origin" correctly to make "good and/or correct" integration in the Figure 7. Some of the considerations/proposals/theories/perspectives about ethnic origins, which are used in the past/present time, are given as follows: (1) all ethnic origins comes from Adam and Eve, and Adam and Eve comes from God; (2) all ethnic origins comes from one nation, and that nation is related with aliens; (3) there are different ethnic origins, and these ethnic origins are related with different gods; (4) different ethnic origins are related with different aliens; (5) all ethnic origins comes from one nation, and that nation is related with one Religion-X; (6) there are different ethnic origins that comes from different nations, and that nations comes from one God; (7) there are different nations that comes from different gods; (8) To talk about "one nation", it is defined that there must be same race and same language for the large group; (9) Some other experts defined "nation" as "group of people sharing common history and usually use common language, usually live in same area"; (10) And some other experts defined "race" as the largest group with same color and/or physical type; (11) Some people can suggest that such large groups used to talk same language at the beginning of the history, then they changed the languages later, but also they come from same race, so all of them are under one nation in that manner; (12) There are eight-ethnic groups due to linguistic phylum; (13) there are three-ethnic groups due to status defined by some experts; (14) ethnic is defined as racial or national or tribal; and (15) others. If these perspectives evaluate generally and specifically, it is possible to define that: (a) there are groups with internal history, which share common history, which have mutual history; (b) there are groups who have 
internal language, common language, mutual language; (c) there are groups living in internal area, living in common area, living in mutual area; (d) there are groups with same ethnic color, different ethnic color, hybrid ethnic color; and (e) there are groups with same physical type, different physical type, hybrid physical type. These statements/definitions, also some other subjects mentioned in this work and in other works, simply indicate that there is something missing about the definition of the nation, and of the race. The author defined "being unique" perspective for living forms in other work (Ramiz, March 2016), which he believes, and he also considered the words "ethnic origin" as "good, correct" definition. With this respect, it is not possible to talk about exactly the "same color", "same language", "same physical type", "same XXX", for different people. However, it is important to consider each ethnic origin (whether they are pure or hybrid) separately for "good and correct" sense of justice. With this respect, R-nation is defined as result of the synthesis, where it includes the following nations and/or ethnic origins generally (in alphabetic order); R-Afghan, R-African, R-American, R-Amerindian, R-Arabic，R-Berber，R-British，R-Chinese，R-Egyptian，R-French，R-German，R-Greek, R-Indian, R-Indonesian, R-Iranian, R-Italian, R-Japanese, R-Jewish, R-Korean, R-Kurd, R-Malay, R-Nepalese, R-Pakistani, R-Russian, R-Saudis, R-Scandinavian, R-Spanish, R-Thai, R-Turk, R-Ukrainian, R-Hybrid, and others. Here, the R-Ethnic Origin is defined below as complementary part of the ideal political construction, and more specific information are given in other work.

R-Ethnic Origin (c, s, l) = Function $\{$ country(ies); structure of person; language(s) $\}$

Structure of Person $=$ Function $\{$ gender types, ethnic color types, physical types, others* $\}$

Here c-denotes "country", s-denotes "structure", 1-denotes "language". It is possible to define the following eight-conditions for the equation (1) in general manner; (a) $c=$ same, $s=$ same, $1=$ same, (b) $c=$ same, $\mathrm{s}=$ different, $\mathrm{l}=$ same, $(\mathrm{c}) \mathrm{c}=$ different, $\mathrm{s}=$ same, $\mathrm{l}=$ same, $(\mathrm{d}) \mathrm{c}=$ same, $\mathrm{s}=$ same, $1=$ different, $(\mathrm{e}) \mathrm{c}=$ same, $\mathrm{s}=$ different, $\mathrm{l}=$ different, $(\mathrm{f}) \mathrm{c}=$ different, $\mathrm{s}=$ same, $\mathrm{l}=$ different, $(\mathrm{g}) \mathrm{c}=$ different, $\mathrm{s}=$ different, $\mathrm{l}=$ same, (h) $\mathrm{c}=$ different, $\mathrm{s}=$ different, $\mathrm{l}=$ different. However, as mentioned above, only the country can be "same" exactly, the other conditions could be consider as "similar". Although some people can think to "unite two countries" and/or "use common language", structure of the persons of two countries will be different. Some other people can think to "unite man and women of two different countries" to establish "one nation", due to his/her political ideology, in this case some people should notice that new born will be "R-hybrid" and "unique" again. If one needs to define a nation, it could be possible to define R-nation as follows.

$$
\text { R-Nation }=\text { Function }\{\text { R-ethnic origin }(c, s, 1) \text {; belief }(c, s, 1) \text {; traditions }(c, s, 1) \text {; other** }\}
$$

In this case, there must be a "good and/or correct" purpose for that. Here, it is possible to define similar eight-conditions for three components of the R-Nation in general manner to guide some people to understand the possible "good/correct" purposes. In case of all R-ethnic origin, belief and traditions triple are same, one can define R-Nation-Pure, otherwise it will be R-Nation-Hybrid. Author considered "R-Ethnic origin-Pure", "R-Ethnic origin-Hybrid", "R-Nation-Pure", "R-Nation-Hybrid" possibilities at the same time for the purpose of "progression" in world countries and/or in regional unions and/or for the social progression of the people.

With this respect, Brazilian Spanish, Chinese Thai, Egyptian Arabic, Greek Cypriot, Indian American, Iraqi Kurd, Syrian Arabic, Saudi Arabic, Syrian Kurd, Syrian Turk, Turkish Cypriot, Vietnam Thai, and other similar definitions (in alphabetic order) are "correct" definitions.

Some of the dimensions/perspectives/concepts, which are given in Table 7 above, and are related with these ethnic origins are generally/specifically explained below (in alphabetic order): 
Progressive Religion: It is defined as result of the synthesis, and as a part of R-Religion as mentioned in other work (Ramiz, March 2016). It includes upper level synthesis comparing with the Progressive Judaism and Progressive Christianity concepts. More general/specific definition is given in other work.

Religion: It denotes one of the past/present religion in a country.

$\boldsymbol{R}$-Centrism: It is defined as result of the synthesis. In one sense, it defines an "over politics" ideology, philosophy. In other sense it includes, defines, considers, and/or represents different levels/characteristics of centrism perspectives; $\mathrm{N}$-constructional centrism (given above for a world country), M-constructional centrism (for a regional union), W-constructional centrism (for world countries' union), U-constructional centrism (for universal structure), democratic centrism, others.

R-Democracy: It is defined by the author, and includes the following cases, separately and together: (1) It is a democracy, which is defined with the administration systems given in (Figure $1 \& 2 \& 3 \& 4 \& 5 \& 6$ ); (2) it is the democracy which is defined with R-sense of justice gave above; (3) it is the democracy which is defined with the types of system administrations in Table 2; (4) it is the democracy defined with the country presidency in Table $3 \& 4 ;(5)$ it is the democracy defined with the ideal political construction in (Table $5 \& 7$; Figure 7). (6) it is the representation of 5 to 5 groups (new defined ones, not the old ones) in the country; (7) it is the representation of men and women; (8) it is the representation of young age, middle age and old age people for some organizations; (9) it is a democracy where some/most/all "decisions" can be taken by related administrator(s) (due to subjects of services, due to administration systems, due to new one framework), and due to "good and correct, or correct" (a) experience, (b) information level, (c) information science, (d) wisdom, (e) functional position level, (f) ethics, (g) R-sense of justice, (h) values, (i) education, and (j) principles they have. These ten characteristics/perspectives/values are proposed for the persons who are in nine-new groups of Table $5 \&$ 7, and are in a position gave with Figure 7, \& 9, \& 10 in general/specific manner; (10) it is the democracy where it is proposed to integrate all the groups into the ideal political construction; (11) it is the democracy where the bad and/or incorrect ones cannot be represented in the administartive and/or representative parliament of country or of a union; (12) it is the democracy where one/some/most/all "decisions" (due to subjects of services) can take by one-new group, or 5-new groups (in row-1 or in column-1), or nine-new groups (in column-1 and in row-1) in Table 7, and due to article-9 above; (13) it is the democracy where each of the 25 sub groups can introduce their opinions (due to subjects of services); (14) it is the democracy where "some agreements" can be taken by 25 sub groups with $50 \%<$ vote/agreement $\leq 60 \%$ (for subject-AA), or $60 \%<$ vote/agreement $\leq 70 \%$ (for subject-BB), or $70 \%<$ vote/agreement $\leq 80 \%$ (for subject-CC), or $80 \%<$ vote/agreement $\leq 90 \%$ (for subject-DD), or $90 \%<$ vote/agreement $\leq 100 \%$ (for subject-EE). General subjects are; quality of services about Subject-3, 4, 9, 10, 11, 14, 16, 18, 27, 28, 33, 34, 35, 36, 37 (Ramiz, March 2016). For these subjects five level optional questionnarie are proposed to be arrange by "experienced" people. Specifically some other subjects are fixed as mentioned with 27 result cases of the synthesis, and these subjects and/or other subjects which are directly/indirectly related with these fix specific subjects, cannot be voted because of its nature, and because of the information level of the community and of some/most politic people cannot be sufficient about all of the 37 subjects to make good and/or correct decision, and because of some other subjects mentiond in this work. The solutions of most/all the problems are already known, and author generally/specifically defined what should do in short, mid, long period (Ramiz, 2015; Ramiz, 2016; others) for the solutions of the problems; and (15) others.

$\boldsymbol{R}$-Monetarist: In one sense it includes, defines, considers, and/or represents different levels/characteristics 
of monetarist perspective. It defined with all of the 11 constructional methods given above.

$\boldsymbol{R}$-National: In one sense it includes, defines, considers, and/or represents different levels/characteristics of national perspective. It defined with all of the 11 constructional methods given above.

R-Progressive: In one sense it includes, defines, considers, and/or represents different levels/characteristics of progressive perspective. It defined with all of the 11 constructional methods given above.

$\boldsymbol{R}$-Religion: It is defined as result of the synthesis, and includes the following cases, separately and together: (1) It is highest level synthesis comparing with Progressive Religion; (2) It is defined as synthesis of the relations between "living forms" and "religion" expressed in other work (Ramiz, March 2016); (3) It is a kind of synthesis of all religions, sects, beliefs in the world; (4) It is a kind of synthesis of beliving god, not beliving god, neither believe nor disbelive in god; (5) It is a kind of synthesis of all theories of religion; (6) It is a kind of synthesis of all mythologies in the world; and (7) More general/specific definition is given in other work.

R-Social: In one sense it includes, defines, considers, and/or represents different levels/characteristics of social perspective. It defined with all of the 11 constructional methods given above.

$\boldsymbol{R}$-Unity: In one sense it includes, defines, considers, and/or represents different levels/characteristics of unity values perspective. It defined with all of the 11 constructional methods given above.

$\boldsymbol{R}$-Values: In one sense it includes, defines, considers, and/or represents different levels/characteristics of community values perspective, and other perspectives given in this work. It defined with all of the 11 constructional methods given above.

\section{Ideal Stability Chart and Democratic Centrism}

There is democratic centrism defined in this work, which differs from N-constructional centrism (see Figure 7) in some manner. Constructional centers includes almost fix centrism, which is related with the nature or construction of the ideal political construction. However, democratic centrism is the perspective that is expected from the administrator and/or administration group which is in a position to be choose or appointed among/by 5 -structural groups for some subjects together. The author defined ideal stability chart in Figure 8 below, and 5-political structural groups and/or its five-sub groups are positioned in this chart to control/inspect the stability behavior of these politic groups, and also to evaluate the centrism of a political administrator person who can be in a position to be chosen/or appointed for some subjects due to the selection called R-democracy.

Here, the groups in the Figure 8 are as follows; group-1; New Era Group or its sub group(s), group-2; progression of the country group or its sub group(s), group-3; unity of the country group or its sub group(s), group-4; values of the country group or its sub group(s), group-5; social progression group or its sub group(s). In this Figure 8; " $\mathrm{d}_{\mathrm{x}}$ " denotes the positions of the possible administrator person or group due to the group-1 \& 2 \& $3 \& 4$ \& 5. AX-BX: stability region for New Era Politic Group, BX-CX: stability region for progression of the country politic group, CX-DX: stability region for the unity of the country politic group, DX-EX: stability region for the values of the country politic group, EX-AX: stability region for the social progression politic group. In case of a politic person is in a position to be selected as administrator person for "some" politic responsibility by the 5-politic groups or persons (democratic selection), it is obvious that administrator person that will be chosen can be "maximum good" most of the time because of the positions of the group $1 \& 2 \& 3$ $\& 4 \& 5$, and position of the administrator person to be choose. 


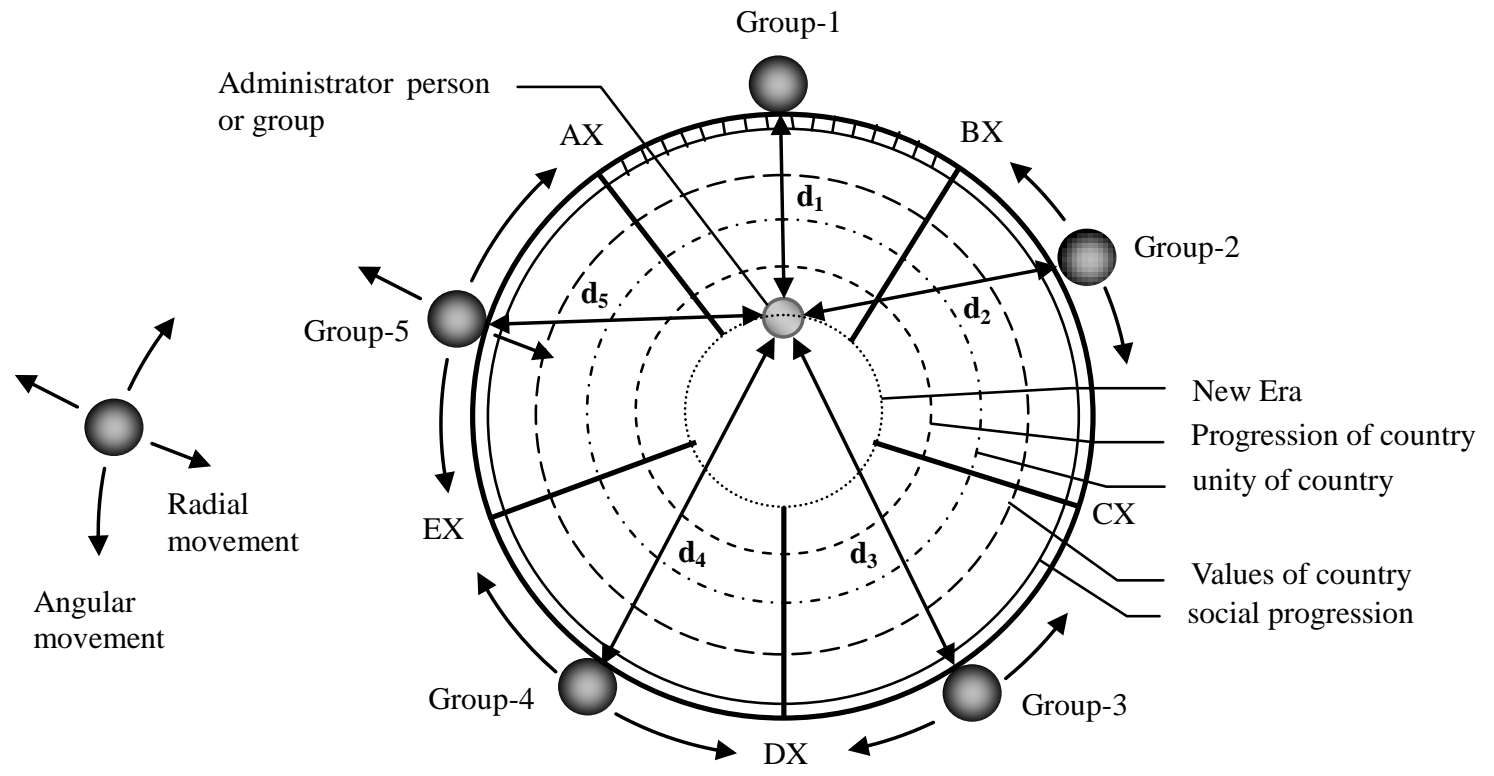

Figure 8. Ideal stability chart and democratic centrism for an administrator and/or group.

However, selection can be possibly "better" (see levels of the 8-basic senses, Ramiz, January 2016) in case of the all politic persons/groups who will make the selection are at (Gr.1.1), (Gr.2.1), (Gr.3.1), (Gr.4.1), (Gr.5.1) politic groups (democratic centrism). No doubt, "good and correct" selection can be obtained due to "constructional centrism" where the characteristics of all the groups and the administrator person to be choose are more clear and at constructional centre due to its nature. Which means it is not enough if the 5-politic groups are near to centre, it is important if the politic administrator to be choose have constructional centrism perspective. This shows that some/most/all the time (due to subjects of services), one/some/most of administrator (due to subjects of services) cannot be choose by democracy perspective (R-Democracy), because of the possible bad and/or incorrect results about the democratic selection can effect the stability, continuity, sense of justice in the administration system(s) of the country (see effective weight function, importance of each of the subjects of services). If one extend the "democracy" perspective for the political elections of some politics by community, there is/are problem(s) about the meaning and/or definition and/or "way of using" and/or "purpose" of the past/present "democracy" perspective. It is important why, where, when, how and with whom the "democarcy" must be considered. Author defined R-democracy to modify, to re-construct it in this manner. There are/were some group(s): (a) who considered "democracy" for some "bad and/or incorrect" purposes; (b) who are/were in a conflict about the purpose of the democracy; (c) who are/were confused about the purpose of the democracy; (d) who considered "democracy" for some "good and/or correct" purposes; (e) who considered democarcy for mutual dispute; and (f) others. Due to political perspective, it is possible to categorize the democratic selection cases as: (a) due to number about subject-A; (b) due to number and content about subject-A; and (c) due to content of subject-A. In this case "political priority" becomes important. Political priority can be good, bad, right, wrong in simple manner, but priority of the continuable political administration system is more important and stable comparing with the political priority of a politicial group or party. Simply it is because of "continuity", "stability" "sense of justice" and other effective weight parameters related with the administration system. With this respect, for "all" subjects, the selection case-(c) "content" 
above must be considered, for some subjects "number", for some subjects "number and content". Some people considered "number" and asked for majority, because of they have majority about that subject-A, but same people did not applied this majority principle for another subject-B, because they are not majority about that subject-B. There are more bad and/or incorrect examples about this. Infact the subject must be if the content of subject-A or subject-B is "good and/or correct". The purpose of the democracy is simply related with "subjects" of "services". 99(+) perspectives (Ramiz, March 2016) are "good and/or correct" guide to make some politic/non-politic perople to understand the "good and/or correct" "way of using the democracy". The democracy perspective can be categorize as; to use it for "all" of the subjects, to use it for "most" of subjects, to use it for "some" subjects, to use it for "one" subject in other manner. It is defined by R-democracy, that democracy perspective can be use for "some" subjects. Author defined the possible "good and/or correct" decision ratio for a person who is in a position to choose another person due to his personal character and/or due to his ideology, in other work (Ramiz, Januray 2016). This is also indicating the importance of the "basic senses" and "sense of justice". If the information about the political person to be choose as administrator, and his/her ideology assume as correct, and also if the person(s) who will evaluate this political person(s) is/are "correct", it is noticed that, possible "good and correct" decision rate of a person who makes the evaluation is nearly $3.69 \%$, possible "good and/or correct" decision rate is nearly $26.77 \%$, and possible "bad and/or incorrect" decision rate is nearly $44.62 \%$, and it is very high. This can be applied to each of the person/group in the ideal stability chart, and the quality/performance and/or correctness level of the democratic selection, democratic centrism can be better understand by comparing with the constructional centrism as well. This way of choosing can be extend to the evaluation of "character of person", "ideology of person", "expertise (education) of person" and others (see person's nature, Ramiz, January 2016). And this shows that "the past/present democracy perspective" cannot apply to "all" of the subjects, or "most" of the subjects. It is good and/or correct to use "senses of justice" most/all of the time comparing with democratic selection. To apply "sense of justice" for most/all the time, "nine-new groups" are defined in ideal political construction table, so that possible instability of some past/present politic/non-politic groups in Table 7 cannot effect the continuity and other subjects of the administration system.

On the other hand, it is possible to use sub-parameters for each of the five circles in the ideal stability chart (stability chart-A), and extend the stability evaluation to more specific circles. With this respect, for example, circle-2; monetary, circle-3; national, circle-4; conservative, circle-5; social, can be considered (stability chart-B), and when applied to behavior of administrator and/or group, the possible variations or instability can be noticed better. Similarly, these circles can be choose as old ideologies (stability chart-C) and the possible variation or instability of administrator and/or group can be noticed in that manner.

The author evaluated all the possible parameters about the ideology and defined the ideal political construction (Ramiz, 2015) and sub ideologies (see Table 5 \& 7) as part of R-Ideology. There are 11-constructional methods given above to describe R-Ideology, and one of them is given below with more specifically;

$$
\text { R-Ideology = I \{W; NoE; i; j; KoS; SoS; WoS; ST; P; r; t; others }\}
$$

Where, I; ideology of person or group defined in ideal political construction (see Table 5 \& 7), W; world country, NoE; ethnic origin of an administrator or group, i; group number (1 to 5), j; sub group number (1 to 5), $\mathrm{KoS}$; kind of services, Sos; subjects of services, WoS; way of services, ST; service types, P; person, r; location, 
t; time, others; defined in this work and in other articles (Ramiz, March 2016; Ramiz, September 2015; Ramiz, January 2016).

\section{Value of a Country}

Although there are various evaluation criterions for world countries, which applied by some national/international organizations, and/or standard associations as a kind of inspection parameter, it is proposed that, value of a country can be measure through the following criterion;

Value of a Country $=V_{1} x($ New Era $)+V_{2} x$ (Progression of the Country) $+V_{3} x$ (Unity of the Country) +

$$
\mathrm{V}_{4} \mathrm{x} \text { (Values of the Country) }+\mathrm{V}_{5} \mathrm{x} \text { (Social Progression) }
$$

\section{Effective Weight of a World Country (EW)}

The author also defined the effective weight (EW) function of a world country below to evaluate the performance/quality of the country in a region and/or in the world. This new function is defined to guide some people to understand the importance of the applications of the political/non-political administration systems for the world countries, and to understand the importance of the other perspectives considered due to the 27 inevitable case results of the synthesis.

Effective Weight of a Country $(\mathrm{EW})=\left[\mathrm{R}_{1} \mathrm{x}\right.$ (Sense of Justice) $]+\left[\mathrm{R}_{2} \mathrm{x}\right.$ (basic senses) $]+\left[\mathrm{R}_{3} \mathrm{x}\right.$ (Information Science) $]+\left[\mathrm{R}_{4} \mathrm{x}\right.$ (Ideal Political Construction of Country) $]+\left[\mathrm{R}_{5} \mathrm{x}\right.$ (Information) $]+\left[\mathrm{R}_{6} \mathrm{x}\right.$ (Systems' Administrations) $]+\left[\mathrm{R}_{7} \mathrm{x}\right.$ (Political Administration System of Country) $]+\left[\mathrm{R}_{8} \mathrm{x}\right.$ (Effective Subjects of Services in Country) $]+\left[R_{9} x\right.$ (Country Presidency) $]+\left[R_{10} x\right.$ (Administrator Persons) $]+\left[R_{11} x\right.$ (Infrastructure of Country) $]+\left[R_{12} \mathrm{x}\right.$ (Effective run of institutions in country) $]+\left[\begin{array}{lll}\mathrm{R}_{13} \mathrm{x} & \mathrm{x}\end{array}\right.$ (Continuity/Sustainability in Country) $]+\left[R_{14} x\right.$ (Natural sources and energy in country) $]+\left[R_{15} x\right.$ (Population in country) $]+\left[R_{16} x\right.$ (Military Power of country) $]+\left[R_{17} x\right.$ (Value of Country) $]+\left[R_{18} x\right.$ (number and level of educated people in Country) $]+\left[R_{19} x\right.$ (Financial/Monetary Power of Country) $]+\left[R_{20} x\right.$ (Surface area of country) $]+\left[R_{21} x\right.$ (Geographical Position of Country) $]$

\section{Ideal Political Construction for a Regional Union}

These regional unions include a kind of synthesis of "ideology-A" and "anti ideology-A" in simple manner. Which means any regional union is not proposed to have such an ideological anti perspective wholly because of its new defined nature. With this respect, ideal political construction for each regional union gave below (see Table 8).

Table 8

Ideal Political Construction for a Regional Union (Groups and Their Sub Groups)

\begin{tabular}{|c|c|c|c|c|c|c|c|}
\hline $\begin{array}{l}\text { 1. New Era Politic Group } \\
\text { for the Regional Union }\end{array}$ & $\begin{array}{r}\text { 2. Pol } \\
\text { Pro } \\
\text { R }\end{array}$ & $\begin{array}{l}\text { Group for the } \\
\text { sion of The } \\
\text { lal Union }\end{array}$ & $\begin{array}{r}\text { 3. P } \\
\text { Unity }\end{array}$ & $\begin{array}{l}\text { Group for } \\
\text { he Regional } \\
\text { nion }\end{array}$ & $\begin{array}{l}\text { 4. Pol } \\
\text { Value }\end{array}$ & $\begin{array}{l}\text { up for the } \\
\text { Regional } \\
\text { n }\end{array}$ & $\begin{array}{l}\text { 5. Politic Group } \\
\text { Social Progressi } \\
\text { the Regional U }\end{array}$ \\
\hline .. (M.N.1.1) & 1.1.2.1) & (M.N.2.1) & $(1.1 .3 .1)$ & (M.N.3.1) & $(1.1 .4 .1)$ & (M.N.4.1) & $(1.1 .5 .1) \ldots(\mathrm{N}$ \\
\hline ... (M.N.1.2) & (1.1.2.2) & (M.N & (1.1.3.2) & (M.N.3.2) & $(1.1 .4 .2)$ & (M.N.4.2) & $(1.1 .5 .2)$ \\
\hline ... (M.N.1.3) & $(1.1 .2 .3)$ & (M.N.2.3) & $(1.1 .3 .3)$ & (M.N.3.3) & $(1.1 .4 .3)$ & (M.N.4.3) & $(1.1 .5 .3)$ \\
\hline (M.N.1.4) & 1.1.2.4) & (M.N.2.4) & $(1.1 .3 .4)$ & (M.N.3.4) & $(1.1 .4 .4)$ & & $(1.1 .5 .4)$ \\
\hline$\ldots \quad$ (M.N.1.5) & $(1.1 .2 .5)$ & (M.N.2.5) & $(1.1 .3 .5)$ & $\ldots$ (M.N.3.5) & $(1.1 .4 .5)$ & (M.N.4.5) & $(1.1 .5 .5) \ldots$ (M.N.5.5) \\
\hline
\end{tabular}

Notes. Here (i, $\mathrm{j}, \mathrm{k}, \mathrm{l})$ denotes; $\mathrm{i}$; number of the country in regional union, $\mathrm{j}$; number of the ethnic origin in each country, $\mathrm{k}$; structural group number in the country, $\mathrm{l}$; number of the sub group in the structural group; $\mathrm{i}=1$ to $\mathrm{M}, \mathrm{j}=1$ to $\mathrm{N}, \mathrm{k}=1$ to $5,1=1$ to 5 . 
There are some political international organizations in the world or in some regions (political international, 2016). Although "some" of them are "good" and needs to be modify or re-construct due to 5-structural group progression perspectives, "some" others "like" communist international, liberal international, socialist international, socialists and democrats international (in alphabetic order) have/had "some" bad and/or incorrect actions/perspectives in the past/or present time, which can cause corruption about progression of the country, unity of the country, values of the country and social progression of the people in that country. There are/were "some" "good and incorrect, incorrect, bad" actions/perspectives in other political organizations about all other integrated (Gr.i.j) groups in Table $5 \& 7$, too (except new defined ones). With this respect, these five new regional union groups in (see Table 8) are "not" like "social international politic group" for example, where one/some/most/all of its members are/were trying to make a whole group-five (see Table 5 or Table 7) in some country to have "same socialist mentality" (although there are Gr.5.1, Gr.5.3, Gr.5.4 perspective in that country), then to ask for from that group five to make that country all "socialist" just like "socialist international politic group", then ask for all group 5 (see Table 8) in a regional union to make all regional union "socialist". Same situation is/was valid for some "liberal international politic group(s)" (although there are Gr.2.1, Gr.2.3, Gr.2.4, Gr.2.5), and for some "communist international politic group(s)". The "good and/or correct" perspectives are defined for such political international organizations with the following new regional structural politic groups (Table 8); New Era Politic Group for the Regional Union, Politic Group for the Progression of The Regional Union, Politic Group for Unity of The Regional Union, Politic Group for the Values of The Regional Union, Politic Group for the Social Progression of the Regional Union People. With this respect, these three past/present political international organizations, which are gave above for example, have two possibilities: (1) they can consider that they are integrated to the ideal political construction and into (Gr.2.2), (Gr.5.2), (Gr.5.5.), and they can modify themselves due to "new" ideologies defined for these new groups (see Table 5); and (2) they can start from these integrated groups and make a synthesis as mentioned in (Table 6) to reach "good and/or correct" stable positions in the ideal political construction (see Table $5 \&$ Table 7). Same possibilities are valid for the politic groups gave for world countries' union in Table 8.

With regarding Table 8, Table 7 and Figure 7, it is possible to show the integration of all of the politic groups, religious groups, ethnic groups, scientific groups, philosophical groups, ideological groups, business groups, R-Hybrid group(s) to the new regional construction system in one figure as it is given in Figure 9 below. This figure (see Figure 9) also defines the new regional centers that are country specific and regional union specific.

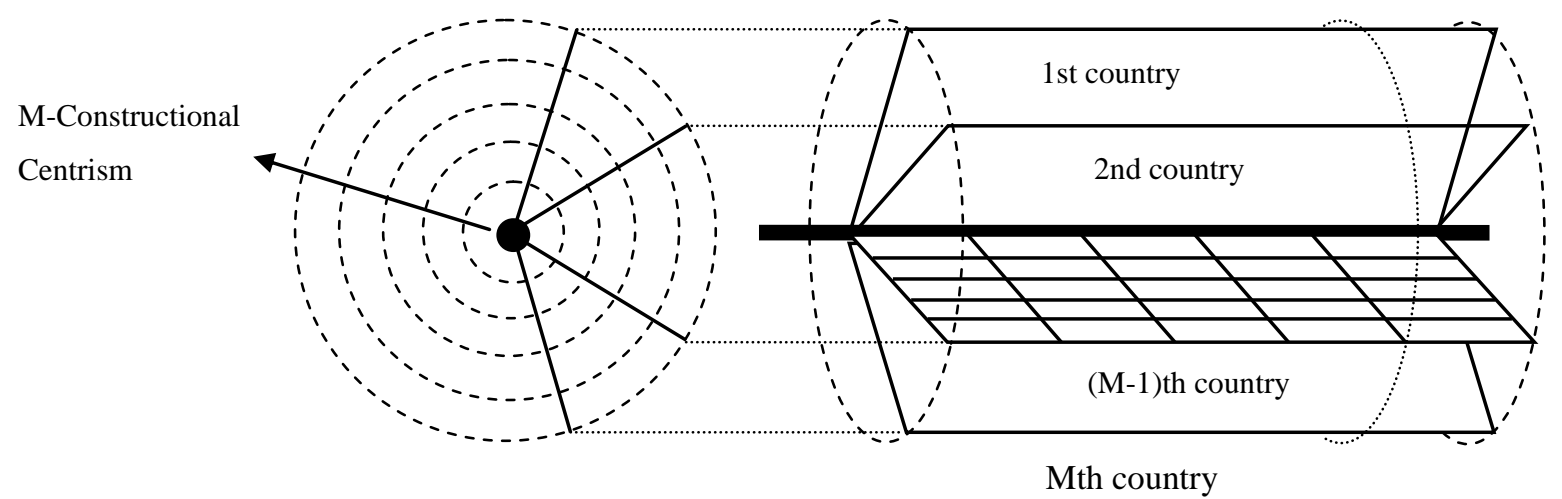

Figure 9. Structural groups in a regional union ( $M \times N \times 5 \times 5$ groups). 


\section{Ideal Political Construction for the World Countries' Union}

With regarding the world countries' union, same/similar perspective which is given in previous section can be consider. With this respect, the author defined ideal political construction for world countries' union (see Table 9). With regarding Table 9, Table 7, and Figure 7, it is possible to show the integration of all of the politic groups, religious groups, ethnic groups, scientific groups, philosophical groups, ideological groups, business groups, R-Hybrid group(s) to the new world union construction system, in one figure as it is given in Figure 10 below. Figure 10 also defines the new worldwide centers that are country specific and world specific. Here the author defined R-Centrism as an "over politics" ideology, philosophy in some manner, and it includes N-Constructional Centrism, M-Constructional Centrism, W-Constructional Centrism, and in general manner U-Constructional Centrism perspectives (where N-denotes country case, M-denotes regional case, W-denotes worldwide case, U-denotes the Universe/Cosmos case).

Table 9

Ideal Political Construction for World Countries'Union (Groups and Their Sub Groups)

\begin{tabular}{|c|c|c|c|c|c|c|c|c|c|c|}
\hline \multicolumn{2}{|c|}{$\begin{array}{l}\text { 1. New Era Politic } \\
\text { Group for the World } \\
\text { Countries }\end{array}$} & \multicolumn{2}{|c|}{$\begin{array}{l}\text { 2. Political Group for the } \\
\text { Progression of The World } \\
\text { Countries }\end{array}$} & \multicolumn{2}{|c|}{$\begin{array}{l}\text { 3. Political Group for the } \\
\text { Unity of The World } \\
\text { Countries }\end{array}$} & \multicolumn{3}{|c|}{$\begin{array}{l}\text { 4. Political Group for the } \\
\text { Values of The World } \\
\text { Countries }\end{array}$} & \multicolumn{2}{|c|}{$\begin{array}{l}\text { 5. Political Group for } \\
\text { the Social Progression } \\
\text { of the World Countries }\end{array}$} \\
\hline (1.1.1.1) & $\ldots \quad$ (W.N.1.1) & $\begin{array}{lll}(1.1 .2 .1) & \ldots \\
\end{array}$ & (W.N.2.1) & $(1.1 .3 .1) \quad \ldots$ & & $(1.14 .1)$ & & & $(1.1 .5 .1) \ldots$ & \\
\hline & . (W.N & $(1.1 .2 .2)$ & & $.1 .3 .2)$ & & & & & $(1.1$ & \\
\hline & - (W.I & & & (1.1.3.3) & & & & & (1.1. & \\
\hline & . (W.I & & & (1.1.3.4) & & & $\cdots$ & & (1.1 & \\
\hline (1.1.1.5) & (W.N.1.5) & (1.1.2.5) & (W.N.2.5) & $\begin{array}{ll}(1.1 .3 .5) & \ldots\end{array}$ & (W.N.3.5) & (1.1.4.5) & .. & (W.N.4.5) & $(1.1 .5 .5) \ldots$ & (W.N.5.5) \\
\hline
\end{tabular}

Notes. Here (p, q, r, s) denotes; p; number of the country in the world, q; number of the ethnic origin in each country, r;structural group number in each country, $\mathrm{s}$; number of the sub group in each structural group, $\mathrm{p}=1$ to $\mathrm{W}(200+), \mathrm{q}=1$ to $\mathrm{N}, \mathrm{r}=1$ to $5, \mathrm{~s}=1$ to 5 .

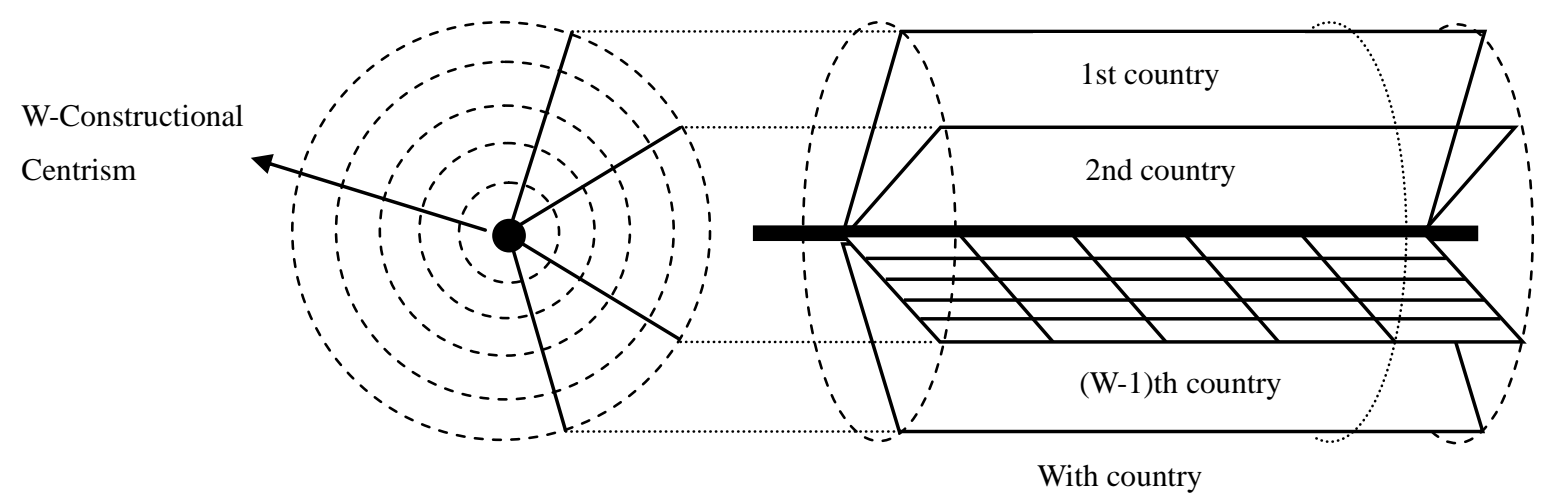

Figure 10. Structural Groups in World Countries Union (WxN $x 5 x 5$ groups).

\section{General Comparison With the Past/Present Political/Non-Political Systems}

In this work, the 27(+) inevitable result cases of the R-synthesis are applied to the all units of the political/non-political systems in the world, generally/specifically. With this respect: (1) some new units added to the systems; (2) some units are balanced; (3) the priority of some units changed; (4) some common units considered; (5) transition period considered for some units; (6) some converge subjects defined for some units; (7) all units are defined and unified under one framework; (8) new subjects defined for some units; (9) importance of education for each unit increased; (10) some units eliminated; (11) some units fixed; (12) 
possible waving about some units limited within some ranges; (13) values of some units improved; (14) all units integrated; (15) the author made general/specific judgment of the world history together with the synthesis, and applied the results of the synthesis to the systems, and so to the units of the systems; (16) some units kept (protected); (17) some units modified; (18) progression proposed for all units; (19) general/specific rules defined for units; (20) some units re-constructed; (21) some units re-defined; (22) some units removed but new units put instead immediately; (23) revolution proposed for each units; (24) some units separated; (25) training proposed for all units; (26) some units unified; (27) some units unified in upper union; (28) functional position level of the units re-constructed; and (29) others.

With regarding the basic forms of the government (Political systems, 2015), some experienced people can realize the differences, similarities, or common points generally/specifically by comparing the five administration systems, systems' administrations (see Figure 6), country presidency structure in (see Table $2 \&$ Table 3 \& Table 4), ideal political construction, and other subjects defined in this work and in previous works (Ramiz, March 2016).

With this respect, the past/present power sources (authoritarian state, democracy, monarchy, oligarchy, republic, other) are re-arranged, or changed, or re-constructed as "hybrid-power source". And despotism, dictatorship, anarchy, anocracy are eliminated/removed. Almost same power source is defined for all the world countries, which is a kind of hybrid form of (authoritarian, democracy, monarchy, oligarchy, republic, minarchism) in general manner.

The past/present power structures (Chiefdom, Confederation, Empire, Federation, Hegemony, Unitary state) are re-arranged, or changed, or re-constructed as new power structures which are re-constructed/re-defined as "country", "country union", “countries' union”, “regional countries' union”.

Organs of government are re-constructed, and principle named as "separation of powers (separation of powers, 2015)" is considered but re-defined.

Public administration is re-constructed from bureaucracy, adhocracy to new reconstructed structure.

Political administration systems are re-constructed/changed/re-defined as "Country Presidency System", “Country Union Presidency System”, “Countries' Union Presidency System”, "Regional Countries' Union (RCU) Presidency System". These systems are a kind of hybrid form of city state, democracy, monarchy, parliamentary, presidential, semi-presidential, feudalism, others, in some manner. Almost same political administration system is defined for most of the world countries. The differences are included in the system by using the "country name" in the "country presidency system" sentence. And anarchism, dictatorship, etc. are eliminated/removed.

\section{Applications and Realization of the New Methods and Theories}

The author considered the new methods and theories, which are defined above and in other work (Ramiz, March 2016), and here applied them to the world countries. With this respect, he defined new political construction for different party systems, different federations below, and also defined regional unions for the world countries.

\section{New Political Constructions Proposed for Different Party Systems in the World}

In this section, all types of party system available in the world countries in present time (party system, 2015; list of ruling political parties by country, 2015), are evaluated and country names are expressed below 
due to party system considered.

Multi-party system by country (132 countries) (in alphabetic order); Afghanistan, Aland, Albania, Andorra, Anguilla, Argentina, Austria, Belarus, Belgium, Bolivia, Bosnia and Herzegovina, Brazil, Bulgaria, Burundi, Canada, Central African Republic, Chile, Colombia, Comoros, Cook Islands, Costa Rica, Cote d'Ivore, Croatia, Czech Republic, Denmark, Dominican Republic, East Timor, Ecuador, Egypt, El Salvador, Estonia, Faroe Islands, Fiji, Finland, France, French Guiana, French Polynesia, Gaza (Palestine), Georgia, Germany, Greece, Greenland, Guadeloupe, Guatemala, Honduras, Hungary, Iceland, India, Indonesia, Iraq, Ireland, Israel, Italy, Japan, Jordan, Kenya, Kiribati, Kyrgyzstan, Kosovo, Latvia, Lebanon, Liberia, Libya, Liechtenstein, Lithuania, Luxembourg, Macau, Macedonia, Madagascar, Malawi, Maldives, Mali, Mauritania, Mauritius, Mayotte, Mexico, Moldova, Mongolia, Montserrat, Morocco, Myanmar, Nagorno, Nepal, Netherlands, New Caledonia, New Zealand, Nicaragua, Niger, Nigeria, Northern Cyprus (TRNC), Norway, Pakistan, Panama, Papua New Guinea, Paraguay, Peru, Philippines, Poland, Portugal, Romania, Saint Kitts and Nevis, Saint Pierre and Miquelon, Sao Tome and Principe, Senegal, Serbia, Sierra Leone, Slovakia, Slovenia, Solomon Islands, South Cyprus (Cyprus), South Korea, Spain, Sri Lanka, Sudan, Suriname, Sweden, Switzerland, Syria, Taiwan, Thailand, Transnistria, Trinidad and Tobago, Tunisia, Turkey, Uganda, Ukraine, United Kingdom, Uruguay, Uzbekistan, Vanuatu, Venezuela, Zambia. Some of these countries have three parties, some have four parties, some have five parties, some have more than two hundred parties.

Two party system by country (38 countries) (in alphabetic order): Algeria, Antigua and Barbuda, Aruba, Australia, Bahamas, Bangladesh, Barbados, Belize, Benin, Bermuda, Bonaire, British Virgin Islands, Cambodia, Cape Verde, Cayman Islands, Chad, Congo, Dominica, Gabon, Ghana, Gibraltar, Grenada, Guam, Guinea, Guinea-Bissau, Isle of Man, Jamaica, Malta, Marshall Islands, Mozambique, Northern Marianas, Palestine, Puerto Rico, Saint Lucia, Saint Vincent and the Grenadines, Seychelles, United States, and Zimbabwe.

Dominant party system by country (37 countries) (in alphabetic order): American Samoa, Angola, Armenia, Azerbaijan, Azores, Bhutan, Botswana, Burkina Faso, Burma, Cameroon, Congo, Curaçao, Djibouti, Dominican Republic, Equatorial Guinea, Ethiopia, Guyana, Iran, Kazakhstan, Lesotho, Malaysia, Montenegro, Namibia, Russia, Rwanda, Saint Helena, Samoa, Singapore, South Africa, Syria, Tajikistan, Tanzania, Togo, Turkmenistan, Turks and Caicos, Uganda, Yemen. These countries have more than one party, but currently and for long period one party or coalition is dominant in that countries.

One party system by country (eigth countries) (in alphabetic order): China*, Cuba*, Eritrea, Gambia, Laos, North Korea, Vietnam, and Western Sahara.

No political party system by country (23 countries) (in alphabetic order): Alderney, Ascension Island, British Indian Ocean Territory, Brunei, Christmas Island, Cocos Islands, Falkland Islands, Guernsey, Kuwait, Micronesia, Niue, Norfolk Island, Oman, Palau, Pitcairn Islands, Qatar, Saudi Arabia, Swaziland, Tokelau, Tonga, Tuvalu, United Arab Emirates, and Vatican City.

Some of these countries have federation system and party system, some others have federation system/party system/monarch system together, some others have party system/monarch system, some others have only party system, and some others have monarch system only. Countries where there are sovereign monarchies gave with its name below.

Sovereign monarchies by country (44 countries) (list of sovereign monarchs, 2016) (in alphabetic order): Andorra, Antigua and Barbuda, Australia, Bahamas, Bahrain, Barbados, Belgium, Bhutan, Belize, Brunei, 
Cambodia, Canada, Denmark, Grenada, Jamaica, Japan, Jordan, Kuwait,Liechtenstein, Lesotho,Luxembourg, Malaysia, Monaco, Morocco, Netherland, New Zealand, Norway, Oman, Papua New Guinea, Qatar, Saint Kitts and Nevis, Saint Lucia, Saint Vincent and the Grenadines, Saudi Arabia, Solomon Islands, Spain, Swaziland, Sweden, Thailand, Tonga, Tuvalu, United Arab Emirates, United Kingdom, Vatican City.

As result of the synthesis, the author defined ideal political construction (see Table 5) for each region, community, territory, state, or country. Also it is proposed to make the integration of each political/non-political group to this ideal political construction as it is generally/specifically expressed in Table 7 and Figure 7.

With this respect, party system is changed, and every region, territory, community, state, or country's political structure is re-constructed based on five-structural groups (5 to 5 groups). As result of the synthesis, 132 countries with multi-party system is proposed to have minimum five political parties and maximum 25 political parties (in both cases five-party system will be valid) due to the size, population, ethnic origin, other characteristics of country or union. Thirty eight countries with two-party system is proposed to have transition period; first stage-integration of the each groups of two parties to 5-structural groups, second stage-establishment of five-party system. Thirty seven countries with dominant party system is proposed to have transition period; first stage-integration to of each groups of party to 5-structural groups, second stage-establishment of five-party system. 8 countries with one party system is proposed to have transition period; first stage-separation of the groups in the party to five-sub-structural groups related with that party ex-ideology (here it is Gr.5), second stage-establishment of five-party system regarding the other sides in all the states, territories, or regions in the country. Twenty three countries with non-partisan/no political party system is proposed to have transition period; first stage- separation and integration to 5-structural groups, second stage-establishment of five-party system. Fourty four countries which currently have sovereign monarchs is proposed to have transition period; first stage- separation and integration of the country people to 5-structural groups, second stage-establishment of five-party system, third stage-reconstruction of hybrid-monarch country presidency system, by considering one of the five suitable political administration system defined with new methods, and considering (see Table $3 \&$ Table 4).

Number of the political party in a state or country is limited as minimum 5 and maximum 25 for each world country as result of the synthesis. Here author believes that this number is "necessary and sufficient" for each world country or state to be progressed, and for the good and/or correct administration, and for the continuity/sustainability. These arrangements will supply various benefits for the related sides. For example, this will make some arrangements about the some political costs, unification of the groups as synthesis proposed, also will be focused on progression of country, social progression, and other subjects. This arrangement will be good and/or correct guide for some people to realize how important is this 5-structural groups' organization for each state or country, once they evaluate 37-subjects of services, separately and together.

\section{New Political Constructions Proposed for Different Federation Systems in the World}

There are 27 different types of federation (Federation, 2016) in the world (in alphabetic order): Argentina, Australia, Austria, Belgium, Bosnia and Herzegovina, Brazil, Canada, Comoros, Ethiopia, Germany, India, Iraq, Malaysia, Mexico, Micronesia, Nepal, Nigeria, Pakistan, Russia, Saint Kitts and Nevis, Somalia, South Sudan, Sudan, Switzerland, United Arab Emirates, United States, and Venezuela. 
Some of these federations have monarch system, different party system, confuse, conflicts, administration problems, and others. The author proposed to re-construct some of these federations as country union, some others as countries' union, and some others as regional countries' union. In all cases, ideal political construction (5 to 5 groups) are defined as mandatory for each federal states or region to realize continuable political administration in that states, and also in the upper federation union. For these federal states, there will be a transition period, where first stage is the integration to the ideal political construction, next stage is the re-construction of the country due to one of the new defined methods. Some of the "good and/or correct" applications of the methods regarding these federations are given in the following section.

\section{Some Applications (Re-Construction) Due to Four Case Theories}

All the case theories (Case-A to Case-D) given above (Ramiz, March 2016) are applied to all the world countries to obtain continuable political/non-political administration in each country and in the world. However, some of the defined applications gave below for some federation countries, for some confused countries, for some countries where there are many conflicts, and also for other "normal" countries. The countries, whose names are not mentioned here also considered for re-construction. The author considered historical names, last names, present names used for some places, subjects, territories, regions, and/or countries, generally/specifically, however applied the R-synthesis, and defined new names which are R-historical, R-present, R-new, R-Hybrid, in some manner. Some/most of these names are given in this work generally or specifically, some others defined in other work with more specifically.

The regional union's are categorized due to "degrees of unions" as: (1) Rxx-primary degree; (2) RRxx-secondary degree; and (3) RRRxx-third degree. Also these regional unions are categoriezed due to their structure as: (a) separate region; (b) common region; and (c) border/crossing region. There are 17 main and progressive regional unions, and 3 progressive regional unions.

Although the word "economy" used for some unions, it is not referring only economy, or economy based policies. The good and/or correct answer is given with the each bloc of the political administration system, and hybrid-category considered due to number of subjects of services included. In some regional union's there are " $(+)$ " which denotes that, there are some other possible countries where they can be add to the related regional union(s). With this respect, hybrid structures of some countries and unions are fixed, and for some other countries and unions there are transition periods.

There are some other federations, or countries where the author proposed reconstruction for them as country union, or regional countries union, but they are not mentioned here.

All of the world countries, whether they are defined inside a regional union or seems outside a regional union (such as Iran, North Korea, other-in alphabetic order), are considered connected with the world union. Until North Korea, Iran, and others fulfill the necessary and sufficient conditions for establishing continuable political administration system in that countries, they are not proposed to be integrated into any regional union nearby them. However, it is proposed to establish ideal political construction with five structural groups within the North Korea, Iran and other countries, parallel to the fulfill procedure.

Author already gave some advices, support, addition about establishment, and/or organizations, and/or re-construction of these case theory applications and/or related sub subjects, and some of them are already realized until now. South East Asia Economic Union (SEAEU) is one of that applications which is officially declared by the related prime ministers and presidents of the 10 countries in 21st November 2015 . 


\section{Applications of the Case-A Theories}

(1) Country: Iraq (Possible Methods-A1, A2, A3);

- Iraq (Method-A1) (parallel to other Case C Theory);

- North Iraq Territory Administration and Iraq government administration $\Rightarrow$ Iraq Union, (Method-A2) (parallel to other Case C Theory).

(2) Country: Syria (Possible Methods-A1, A2, A3);

- Syria (Method-A1) (parallel to other Case C Theory);

- $\quad$ Syria $\Rightarrow$ Syria Union (Method-A2) (parallel to other Case C Theory).

(3) Country: Azerbaijan (Possible Methods-A1, A2, A3);

- Azerbaijan (Method-A1) (parallel to other Case C Theory);

- Azerbaijan and Nakhchivan $\Rightarrow$ Azerbaijan Union (Method-A2) (parallel to other Case C Theory);

- Azerbaijan and Nakhchivan and Other dispute country unification in upper Union (Method-A3) ;

- Azerbaijan (Method-A1), Nakhchivan (Method-A1) (parallel to other Case C Theory).

(4) Country: Palestine (Possible Methods-A1, A2);

- Palestine (Method-A1) (parallel to other Case C Theory);

- Gaza territory and Ramallah* territory $\Rightarrow$ Palestine Union (Method-A2) (parallel to other Case C Theory).

(5) Country: Israel (Possible Methods-A1, B4);

- Israel (Method-A1) (parallel to other Case-C Theory);

- Side-1: Israel, Side-2: Palestine (Case-C: Method-C5, Method-C8 situations);

- Side-1: Israel, Side-2: Palestine (Method-B4) (parallel to other Case Theory).

(6) Country: Belgium (Possible Methods-A1, A2, A3, A4);

- Belgium $\Rightarrow$ Belgium Union (parallel to other Case $C$ Theory).

(7) Country: Afghanistan (Possible Methods-A1, A2, A3, A4);

- Afghanistan (Method-A1) (parallel to other Case Theory);

- Afghanistan $\Rightarrow$ Afghanistan Union (Method-A2) (parallel to other Case Theory).

\section{Applications of the Case-B Theories}

(8) Country: North Cyprus (TRNC) (Possible Methods-A1, B4, B5, B6).

- North Cyprus (TRNC) (Method-A1) (parallel to other Case C Theory);

- North Cyprus (TRNC) and South Cyprus (Cyprus) $\Rightarrow$ Cyprus Union (Method-B4) (parallel to other Case C Theory);

- North Cyprus (Method-B5), South Cyprus (Method-B5) (parallel to other Case C Theory);

- North Cyprus (Method-B6), South Cyprus (Method-B6) (parallel to other Case C Theory).

\section{Applications of the Case-C Theories}

There are different subjects of services and sub-subjects where the author evaluated and made the synthesis under these case theories. As result of the synthesis, different hybrid categories, and hybrid degrees are defined, where each hybrid categories consider same, common, or different number of subjects of services.

Hybrid Category-HC01:

[R1]-Mediterranean-Asia Economic Countries' Union (MedAsia Economic Union) (Method-C5, C8)

Countries (in alphabetic order): Abkhazia**, Adjaria**, Azerbaijan, Egypt*, Georgia***, Iraq, Israel, Jordan, Lebanon, North Cyprus (TRNC)*, Nakhchivan**, Palestine, South Ossetia**, Syria, Turkey*, 


\section{NEW ADMINISTRATION SYSTEMS FOR THE WORLD COUNTRIES AND SENSE OF JUSTICE}

Turkmenistan, South Cyprus*, (+).

General Characteristics: There are 17(+) countries considered. Each of them is at country level, some of the territories $(* *)$ are re-constructed and their levels increased to country level and integrated to upper regional union, while some countries (***) are re-constructed and integrated to upper union. Each country proposed to have ideal political construction. Each country proposed to have a right to make agreement with other world countries, and union is proposed to have a right to make some agreements with other unions due to the theory of countries' union. Some countries (*; other) proposed to have common statue within more than one regional union, because of being at border/crossing of the two regional unions, and because of common community values in two regional unions. Total population of the union is proposed as $271.508 .829(+)$.

Hybrid Category-HC02:

[R2]-American Countries' Union (American Union); (Case-C: Method-C1)

Countries (in alphabetic order): Alabama, Alaska, Arizona, Arkansas, California, Colorado, Connecticut, Delaware, Florida, Georgia, Hawaii, Idaho, Illinois, Indiana, Iowa, Kansas, Kentucky, Louisiana, Maine, Maryland, Massachusetts, Michigan, Minnesota, Mississippi, Missouri, Montana, Nebraska, Nevada, New Hampshire, New Jersey, New Mexico, New York, North Carolina, North Dakota, Ohio, Oklahoma, Oregon, Pennsylvania, Rhode Island, South Carolina, South Dakota, Tennessee, Texas, Utah, Vermont, Virginia, Washington, West Virginia, Wisconsin, Wyoming.

General Characteristics: There are 50 states considered, and each of the state level increased to country statue. Each country proposed to have ideal political construction. Each country proposed to have a right to make agreement with other world countries, and union is proposed to have a right to make some agreements with other unions due to the theory of countries' union. Total population of the union is proposed as 324,118,787 (Population of world countries, 2016; population by country, 2016).

[R4]- Russia Countries' Union (Russian Union); (Case-C: Method-C2, Method-C5, Method-C8)

Countries (in alphabetic order): Adygea, Altai, Bashkortostan, Buryatia, Chechnya, Chuvashia, Dagestan, Ingushetia, Kabardino-Balkaria, Kalmykia, Karachay-Cherkessia, Karelia, Khakassia, Komi, Mari El, Mordovia, North Ossetia, Yakutia, Tatarstan, Tuva, Udmurtia, (+)

General Characteristics: There are 21 republics $(+)$ considered, where each of the republic level increased to country statue. Each country proposed to have ideal political construction. Each country proposed to have a right to make agreement with other world countries, and union is proposed to have a right to make some agreements with other unions due to the theory of countries' union. Total population of the union is proposed as $143,439,832(+)$.

[R5]-Indian Countries' Union (Indian Union) (Case-C: Method-C2)

Countries (in alphabetic order): Andhra Pradesh, Arunachal Pradesh, Assam, Bihar, Chhattisgarh, Goa, Gujarat, Haryana, Himachal Pradesh, Jammu and Kashmir**, Jharkhand, Karnataka, Kerala, Madhya Pradesh, Maharashtra, Manipur, Mizoram, Nagaland, Odisha, Punjab, Rajasthan, Sikkim, Tamil Nadu, Telangana, Tripura, Uttarakhand, Uttar Pradesh, West Bengal.

General Characteristics: There are 28 states $(+)$ considered, and each of the state level increased to country statue. Each country proposed to have ideal political construction. Each country proposed to have a right to make agreement with other world countries, and union is proposed to have a right to make some agreements with other unions due to the theory of countries' union. Jammu and Kashmir** included in India Union as a country, but it will have special agreements with near border Pakistan and Indian Union, and Regional Union(s). 
Total population of the union is proposed as 1,326,801,576 (+).

Hybrid Category-HC03:

[R3]-Britain Countries' Union (Britain Union); (Case-C: Method-C4)

Countries (in alphabetic order): England, Northern Ireland, Scotland, South Ireland (Republic of Ireland)*, Wales, $(+)$

General Characteristics: There are four kingdoms, one country $(+)$ considered. Each of the kingdom level increased to country statue. Each country proposed to have ideal political construction. Each country proposed to have a right to make agreement with other world countries, and union is proposed to have a right to make some agreements with other unions due to the theory of countries' union. Hybrid-Monarch political administration system is considered (Table $2 \& 3 \& 4 \& 7 \& 8$; others). Total population of the union is proposed as $69,825,136(+)$.

Hybrid Category-HC04:

[R6]- China Countries' Union (China Union) (Case-C: Method-C6, Method-C9)

Countries (in alphabetic order): Anhui, Fujian, Gansu, Guangdong, Guangxi, Guizhou, Hainan, Hebei, Heilongjiang, Henan, Hong Kong, Hubei, Inner Mongolia, Jaingsu, Jiangxi, Jilin, Liaoning, Ningxia, Qinghai, Shaanxi, Shanxi, Shandong, Sichuan, Tibet, Xinjiang (Sincan-Uygur), Yunnan, Zhejiang.

General Characteristics: There are 27 territories considered. Each of the territory level is increased to country statue. Each country proposed to have ideal political construction. Each country proposed to have a right to make agreement with other world countries, and union is proposed to have a right to make some agreements with other unions due to the theory of countries' union. Inner Mongolia, Tibet, Xinjiang (Sincan-Uygur) included in China Union as a country, but they will have special agreements with near border countries or Regional Union(s). Total population of the union is approximately 1,382,323,332(+).

Hybrid Category-HC05:

[R9]-South America Economic Countries' Union (South America Economic Union) (Case-C: Method-C5)

Countries (in alphabetic order): Argentina, Bolivia, Brazil, Chile, Colombia, Ecuador, French Guiana, Guyana, Paraguay, Peru, Suriname, Trinidad and Tobago, Uruguay, Venezuela, (+)

General Characteristics: There are 14(+) countries considered. Each country proposed to have ideal political construction. Each country proposed to have a right to make agreement with other world countries, and union is proposed to have a right to make some agreements with other unions due to the theory of countries' union. Total population of the union is proposed as 423.896.753(+).

[R10]-North Africa Economic Countries' Union (North Africa Economic Union) (Method-C5, C8)

Countries (in alphabetic order): Algeria, Benin, Burkina-Faso, Cameroon, Chad, Cote d'Ivoire, Djibouti, Egypt*, Eritrea, Ethiopia, Gambia, Ghana, Guinea, Guinea Bissau, Libya, Morocco, Liberia, Mali, Mauritania, Niger, Nigeria, Senegal, Sierra Leone, Somalia, South Sudan, Sudan, Togo, Tunisia, Western Sahara, (+)

General Characteristics: There are 29(+) countries considered. Each country proposed to have ideal political construction. Each country proposed to have a right to make agreement with other world countries, and union is proposed to have a right to make some agreements with other unions due to the theory of countries' union. Some countries (Egypt*, other) proposed to have common statue within more than one regional union, because of being at border/crossing of the two regional unions, and because of common community values in two regional unions. Total population of the union is proposed as 760.656.118(+).

[R11]-South Africa Economic Countries' Union (South Africa Economic Union) (Case-C: Method-C5) 
Countries (in alphabetic order): Angola, Botswana, Burundi, Cabinda, Central African Republic, Comoros, Democratic Republic of Congo, Equatorial Guinea, Gabon, Kenya, Lesotho, Madagascar, Malawi, Mozambique, Namibia, Rwanda, Sao Tome and Principe, Seychelles, South Africa, Swaziland, Tanzania, Uganda, Zambia, Zimbabwe, (+).

General Characteristics: There are 26(+) countries considered. Each country proposed to have ideal political construction. Each country proposed to have a right to make agreement with other world countries, and union is proposed to have a right to make some agreements with other unions due to the theory of countries' union. Some countries $\left(^{*}\right.$, other) proposed to have common statue within more than one regional union, because of being at border/crossing of the two regional unions, and because of common community values in two regional unions. Total population of the union is proposed as 384.592.328(+).

Hybrid Category-HC06:

[R12]-South-East Asia Economic Countries' Union (South-East Asia Economic Union) (Case-C: Method-C5)

Countries (in alphabetic order): Brunei, Cambodia, Indonesia, Laos, Malaysia, Myanmar, Philippines, Singapore, Thailand, Vietnam.

General Characteristics: There are 10 countries considered. Each of them is at country level. Each country proposed to have ideal political construction. Each country proposed to have a right to make agreement with other world countries, and union is proposed to have a right to make some agreements with other unions due to the theory of countries' union. Total population of the union is proposed as 639.408.058(+). This union is already officially declared by the date of 21 st November 2015 and with the signatures of prime ministers, a president and a sultan as country responsible.

Hybrid Category-HC07:

[RR14]-North America Economic Countries' Union (North America Economic Union) (Case-C: Method-C8).

Countries (in alphabetic order): American Union, Bahamas, British Virgin Islands, Canada, Cayman Islands, Cuba, Dominican Republic, Haiti, Jamaica, Mexico, Virgin Islands, Puerto Rico, Navassa Island, Turks and Caicos Islands, (+).

General Characteristics: There are 14(+) countries considered. Each of them is at country level. Each country proposed to have ideal political construction. Each country proposed to have a right to make agreement with other world countries, and union is proposed to have a right to make some agreements with other unions due to the theory of countries' union. Some countries (*, other) proposed to have common statue within two regional union, because of being at border/crossing of the two regional unions, and because of common community values in two regional unions. Total population of the union is proposed as 529.005.781(+).

[RR15] Eastern-Asia Economic Countries' Union (Eastern Asia Economic Union) (Case-C: Method-C8)

Countries (in alphabetic order): China Union, Japan, Mongolia, South Korea, and Taiwan.

General Characteristics: There are five countries considered. Each of them is at country level. Each country proposed to have ideal political construction. Each country proposed to have a right to make agreement with other world countries, and union is proposed to have a right to make some agreements with other unions due to the theory of countries' union. China has a common statue as another regional countries' union, and because of being at the border/crossing of the two regional unions, because of common community values in two regional unions. Total population of the union is proposed as 1.585.553.024(+). If North Korea fulfill the 
requirements to have good and/or correct continuable administration statue, it is propose to be included to this union.

[RR16] South Asia Economic Countries' Union (South Asia Economic Union) (Case-C: Method-C5)

Countries (in alphabetic order): Bangladesh, Bhutan, Indian Union, Nepal, Sri Lanka.

General Characteristics: There are five countries considered. Each of them is at country level. Each country proposed to have ideal political construction. Each country proposed to have a right to make agreement with other world countries, and union is proposed to have a right to make some agreements with other unions due to the theory of countries' union. India has a common statue as another regional countries' union, and because of being at the border/crossing of the two regional unions, because of common community values in two regional unions. Total population of the union is proposed as 1.540.158.076(+).

Hybrid Category-HC08:

[R8] -Arabian Countries' Union (Arabian Union) (Case-C :Method-C5)

Countries (in alphabetic order): Bahrain, Kuwait, Oman, Qatar, Saudi Arabia, United Arab Emirates, Yemen.

General Characteristics: There are seven countries considered. Each of them is at country level. Each country proposed to have ideal political construction. Each country proposed to have a right to make agreement with other world countries, and union is proposed to have a right to make some agreements with other unions due to the theory of countries' union. Total population of the union is proposed as 81.252.359(+).

[R13]-Middle Asia Turk Economic Countries' Union (MidAsiaTurk Economic Union) (Case-C: Method-C5)

Countries (in alphabetic order): Afghanistan, Kazakhstan, Kyrgyzstan, Pakistan, Tajikistan, Uzbekistan.

General Characteristics: There are 6 countries considered. Each of them is at country level. Each country proposed to have ideal political construction. Each country proposed to have a right to make agreement with other world countries, and union is proposed to have a right to make some agreements with other unions due to the theory of countries' union. Some countries have a common statue because of being at the border/crossing of the two regional unions, because of common community values in two regional unions. Total population of the union is proposed as $289.055 .510(+)$.

Hybrid Category-HC09:

[R7]-European Economic Countries' Union (European Economic Union) (Case-C: Method-C7)

Countries (in alphabetic order and due to regional and/or some common values): (Europa-1) Belgium, France, Germany, Italy, Luxembourg, Netherlands. (Europa-2) England*, Northern Ireland*, Scotland*, South Ireland (Republic of Ireland)*, Wales*. (Europa-3) Austria, Denmark, Finland, Greece*, Norway, Portugal, Spain, Sweden. (Europa-4) Andorra, Hungary, Malta, Monaco, Switzerland. (Europa-5) Belarus*, Crimea**, Czech Republic*, Estonia*, Kaliningrad**, Latvia*, Letonia*, Lithuania*, Moldova*, Poland*, Romania*, Slovakia*, Ukraine*. (Europa-6) Albania*, Bosnia and Herzegovina*, Bulgaria, Croatia*, Macedonia*, Montenegro*, North Cyprus (TRNC*), Serbia*, Slovenia*, South Cyprus (Cyprus)*, Turkey*.

General Characteristics: There are 47 countries considered. 28 are already member of EU (European Union, 2016). Each of them is at country level, one of the territory (**) is re-constructed and its level increased to country level, and integrated to upper regional union, each country proposed to have ideal political construction. Each country proposed to have a right to make agreement with other world countries, and union is proposed to have a right to make some agreements with other unions due to the theory of countries' union. 
Some countries (*) proposed to have common statue within two regional unions, because of being at border/crossing of the two regional unions, and because of common community values in two regional unions. Total population of the union is proposed as 508,200,000(+).

Hybrid Category-HC10:

[RRR 17]-Great Ocean Economic Countries' Union (Great Ocean Economic Union) (Case-C: Method-C5)

Countries (in alphabetic order): American Samoa, Australia, Baker Island, Cook Islands, Fiji, French Polynesia, Guam, Howland Island, Johnston Atoll, Kiribati, Marshall Islands, Micronesia, Midway Atoll, Niue, Nauru, New Caledonia, New Zealand, Northern Mariana Islands, Palau Islands, Papua New Guinea, Samoa, Solomon Islands, Tokelau, Tonga, Tuvalu, Wake Island, Wallis and Futuna Islands, Vanuatu.

General Characteristics: There are 28 countries considered. Although some of them seems as part of another country, each of them is considered at country level, and each of these territories/countries are proposed to have ideal political construction. Each country proposed to have a right to make agreement with other world countries, and union is proposed to have a right to make some agreements with other unions due to the theory of countries' union. Total population of the union is 39,901,355(+).

[RRR18] Euroasia Countries Union (Euroasia Union) (Case-C: Method-C5)

Countries (in alphabetic order): Belarus*, Crimea**, Czech Republic*, Estonia*, Kaliningrad**, Letonia*, Lithuania*, Moldova*, Poland*, Romania*, Slovakia*, Ukraine*, (+).

General Characteristics: There are $11(+)$ countries considered. Some of the communities/territories level are increased to country level and integrated to upper union (**). Each of them is at country level. Each country proposed to have ideal political construction. Each country proposed to have a right to make agreement with other world countries, and union is proposed to have a right to make some agreements with other unions due to the theory of countries' union. Some countries $\left({ }^{*}\right)$ proposed to have common statue within two regional unions, because of being at the border/crossing of the two regional unions, and because of common community values in two regional unions. Total population of the union is proposed as 136,271,261(+).

[RRR19] EuroasiaTurk Economic Countries' Union (EuroasiaTurk Economic Union) (Case-C: Method-C5)

Countries (in alphabetic order): Abkhazia**, Adjaria**, Afghanistan*, Azerbaijan*, Georgia***, Kazakhstan*, Kyrgyzstan*, Nakhchivan**, North Cyprus*, Pakistan*, South Ossetia**, Tajikistan*, Turkey*, Turkmenistan*, and Uzbekistan*, (+).

General Characteristics: There are 15(+) countries considered. Some of the communities/territories level are increased to country level and integrated to upper union (**). Each of them is at country level. Each country proposed to have ideal political construction. Each country proposed to have a right to make agreement with other world countries, and union is proposed to have a right to make some agreements with other unions due to the theory of countries' union. Some countries $(*)$ proposed to have common statue within two regional unions, because of being at the border/crossing of the two regional unions, and because of common community values in two regional unions. Total population of the union is 387,964,470(+).

[RRR20] Balkans Economic Countries' Union (Balkans Economic Union) (Case-C: Method-C5)

Countries (in alphabetic order): Albania, Bosnia and Herzegovina, Bulgaria*, Croatia*, Greece*, Kosovo, Macedonia, Moldova, Montenegro, Romania*, Serbia, Slovenia*. 
General Characteristics: There are 11 countries considered. Each of them is at country level. Each country proposed to have ideal political construction. Each country proposed to have a right to make agreement with other world countries, and union is proposed to have a right to make some agreements with other unions due to the theory of countries' union. Some countries $\left({ }^{*}\right)$ proposed to have common statue within two regional unions, because of being at the border/crossing of the two regional unions, and because of common community values in two regional unions. Total population of the union is proposed as 48,459,335.

\section{Applications of the Case-D Theories}

There are three possible applications for the related theories: (a) establishment of new world countries' union (Method-D1); (b) re-construction of the United Nations (UN) (United Nations, 2010) to establish new world countries' union (Method-D2); and (c) establishment of new world countries' union, and integration of United Nations (UN) to this new system.

\section{Conclusions}

In this work, author expressed some of the results of his synthesis. It is important to consider the content of the previous works (Ramiz, 2015; Ramiz, Januray 2016; Ramiz, March 2016) to understand the content of this work completely. The types of administrations, and possible methods (Case-A, B, C, D) are defined to solve the general and specific problems which are noticed as result of the synthesis in this work and in previous works (Ramiz, March 2016). Here, these four general cases, and 23 main methods are considered, and five categories are defined for administration systems. Each of these methods defined as result of the synthesis, and "some people" should not consider these methods as "option" where they can arrange the orders of these options (or priorities) due to their personal aims, and choose last option due to their past/present ideology, and consider that mentality for the applications about that subjects. Author defined new methods, new theories, new principles, new possibilities, new definitions where "each possibility" include "sense of justice" basically, and each way of application, together or separately, converge to the same "good and correct" purposes. With this respect, "some" politic/non-politic people should notice that these methods and each of the administration systems are defined with "over politic" perspective to supply continuable administration in world countries, or in regions, or in the world. Some of these administration systems can be establish by re-construction of old systems in a world country, while some other present country systems need to change, some other ones need to be re-constructed due to the 27-inevitable results of the synthesis as it is stated in other work (Ramiz, March 2016), and also in this work. In general/specific manner, these new administration systems, related system administration, and the sub blocs which are defined together with these systems, are defined to solve the problems in short, mid, and long period (due to subjects of services) and with systematically. With this respect, general political administration system for a world "country", general political administration system for a "country union", general political administration system for a "countries' union", general administration system for "regional countries' union", and general administration system for the "world countries' union" are defined with its sub blocs. Each bloc is important for the "good and correct" administration, and for the continuity, and for supplying sense of justice, and for progression of the countries. Each bloc includes same/similar content in some manner, and this is one of the results of the synthesis, and necessary for supplying sense of justice, for easy communication between the two or more sides, and for other purposes.

In one sense, some/most/all of the problems about subjects (due to subjects of services) are noticed by the author as result of the synthesis, and the possible solutions of some of these problems will be advise (or already 
advised) to the some experienced people and/or possible responsible of the related blocs of the administration systems. For each of the blocs of the administration systems, the system administration (see Figure 6) and each blocs of the system administration is important, necessary and mandatory.

Each of the letters, words, sentences, tables, figures, definitions, comparisons, theories, methods, etc. within this article are considered specifically, and most of them indicates some real life experienced subjects beside the theoretical information included.

System administration is one of the important part of the systems. The administrator(s) is one of the main subject of the system administration(s) (see Figure 6). So, it is important how an administrator is related with the other blocs of the system administration in Figure 6. In general manner, the system, administrator person and information triple can be a solution to some/most problems or cause problems in the political/non-political administration systems, together and/or separately. It is important to define the "priority" for the consideration of the characteristics of these three effective parameters together. It is proposed that each of these effective parameters can have two possible characteristics; "good" or "bad", in simple manner (more sensitive evaluation is done for eight-basic senses/characteristics, and considering other dimensions of the synthesis, and considering effective weight EW parameters). With this respect, the priorities are defined from highest to lowest level importance (see Table 1), due to characteristics of the system, administrator person and information together, to show the importance of the priorities for Continuable/Sustainable Administration System. The author defined one of the most important subject for the each of the administration system, and for the related blocs, and for the related system administrations of each bloc; the sense of justice. The sense of justice is categorized into 21 cases, generally/specifically. Some of these cases are explained in other work (Ramiz, March 2016) and in this work with some examples about different subjects of services to call attention to the dimension and content of the sense of justice, and of the synthesis considered. Also, some general information are gave in Table 2 about administrator(s) and about number of the administrative person due to the type of the system administration and administration system related. To give a general and specific information about the administration system and system administration, country presidency structure (see Table 3 ) is defined as part of the country presidency system. Table 3 and Table 4 indicates most important characteristic features, and fundamental and representative responsibilities of some political/non-political sides.

An ideal political construction is defined as one of the basic important part of all subjects. With this respect, each of the community, territory, state, or country proposed to have ideal political construction (see Table 5 \& 7). Although some words are enough to explain the ideologies of each of these 5 -structural groups or 25 sub-groups due to philosophical perspective given above, Table 5 is defined to give more information about the content and results of the synthesis, which considers the groups and proposed "good and/or correct" ideologies connected to these sub groups (R-Ideology; Ramiz, 2015). It is important to integrate all political/non-political groups into the ideal political construction of a world country to obtain continuability/sustainability in the system. Of course, the method of integration is important as well. It is important for the people to have "necessary and/or sufficient" information about these perspectives. This is also important part of creating "information society/community". These subjects are explained with figures and definitions in other work (Ramiz, March 2016). Way of integration is another important part of the synthesis (see Table 7). The author generally/specifically explained how it should be done at the beginning, and what should the related groups do at next step to supply necessary and sufficient progression in the country. With this respect, the integration of all of the politic groups, religious groups, ethnic groups, scientific groups, 
philosophical groups, ideological groups, business groups, R-hybrid group(s) to the new construction system is described in one figure as it is given in Figure 7. There are some "new definitions" in Table 5, where author defined as result of the synthesis to characterize each new group ideology due to the dimensions of the synthesis given in the other work (Ramiz, March 2016). There are new definitions in Table 7 which are simply given as (in alphabetic order); Constructional Centrism, Democratic centrism, Progressive Religion, R-Centrism, R-Democracy，R-Monetarist，R-National，R-Progressive，R-Social，R-Unity，R-Values. Also, R-Ideology, R-Religion, R-Science, R-Philosophy, and R-Continuity are defined as related concept with these definitions, to solve the problems. These new dimensions/values/perspectives are defined also by using different 11 methods to describe them in different way of understanding. The author also gave some information about R-ethnic origin, where he defined as complementary part of the ideal political construction for a world country, and/or regional union, and/or for world union.

An ideal stability chart (see Figure 8) is defined for 5-structural groups to criticize/judge/comment/guide the sensitive behavior of an administrator or group due to the five-ideal values they considered instantaneously or time-dependent. Also, same stability figure (see Figure 8) used to show how a political administrator, who is in a position to be chosen for some subjects by five-structural politic groups and due to R-democracy, can introduce a centrism in the political administration system (named as democratic centrism). As it can be noticed from the Figure 8, group-one (New Era Group with five-sub groups) is the most stable group because of its nature, and other five-structural politic groups, except new defined sub groups in Table 7, have more instable behaviors in the political system. These instabilities of the five-political structural groups, no doubt, can effect the democratic centrism of the political administrator person chosen, and/or the democratic centrism of the political administration system. More sensitive evaluation is done in other work.

Although there are various evaluation criterions for world countries, which applied by some national/international organizations, and/or standard associations as a kind of inspection parameter, it is proposed that "value of a country" can be measure through the new criterion, which is also related with the ideal political construction. Author also defined the mathematical effective weight (EW) function of a world country to evaluate the performance/quality/progression/continuity and other levels of the country in a region and/or in the world. This new mathematical function includes 21-dimensions of the progression to guide some people to understand the importance of the applications of the political/non-political administration systems for the world countries, and to understand the importance of the other perspectives considered due to the 27 inevitable case results of the synthesis. Although it seems a mathematical function, it is not because of its 21 dimensions includes different specific branches of ideology, philosophy, religion, and science. As an important part of the effective weight function, R-Continuity is defined by considering very important 21-perspectives/categories, where each category together and separately indicates the sensitivity of the continuity considered.

The author applied the 27(+) inevitable result cases of the R-synthesis to the all units of the political/non-political systems in the world, generally/specifically. Then made a general comparison with the past/present political/non-political systems, and the related basic forms of the government. With regarding the basic forms of the government, experienced people can realize the differences, similarities, or common points generally/specifically by comparing them with the five administration systems, systems' administrations (Figure 6), country presidency structure in (see Table $2 \&$ Table 3), ideal political construction, and other subjects defined in this work and in other work (Ramiz, March 2016). 
In the last section of this work, ideal political construction proposed for different party systems (multi party, two party, one party, dominant party, non-partisan), and for different federation systems in the world. For most countries, it is proposed to make direct application of the ideal political construction, for some others a transition period is advised.

Here also some of the applications (re-constructions) are defined for the world countries due to the Case A \& Case B \& Case C and Case D theories (Ramiz, March 2016). These four case theories (Case-A to Case-D) (Ramiz, March 2016) are applied to all world countries to obtain continuable political/non-political administration in each country and in the world. However, names of the some of the applications gave here for some federation countries, for some confused countries, for some countries where there are many conflicts, and also for other "normal" countries. The countries, whose names are not mentioned here also considered for re-construction. There are some examples about country construction, country union construction, and regional union constructions. The regional union's are categorized due to "degrees of unions" as: (1) Rxx-primary degree; (2) RRxx-secondary degree; and (3) RRRxx-third degree. Also these regional unions are categorized due to their structure as: (a) separate region; (b) common region; and (c) border/crossing region.

Although the word "economy" used for some regional unions, it is not referring only economy, or economy based policies. The author categorized these regional unions due to the hybrid category, where the number of subjects of services considered, to give idea about the considered subjects within the regional unions. The "names" of the regional unions are defined as part of the synthesis, and include good and/or correct hybrid perspective about the following regional unions (in alphabetic order): (1) American Union; (2) Arabian Union; (3) Balkans Economic Union; (4) Britain Union; (5) China Union; (6) Eastern Asia Economic Union; (7) Europe-Asia Union; (8) Europe-Asia-Turk Economic Union; (9) European Economic Union; (10) Great Ocean Economic Union; (11) Indian Union; (12) North Africa Economic Union; (13) Mediterranean-Asia Economic Union; (14) Middle Asia-Turk Economic Union; (15) North America Economic Union; (16) Russia Union; (17) South Africa Economic Union; (18) South America Economic Union; (19) South Asia Economic Union; and (20) South East Asia Economic Union (SEAEU). In some regional union's there are "(+)" signs which denotes that there are some other possible countries where they can be add to the related regional union(s). All of the world countries, whether they are defined inside a regional union or seems outside a regional union (such as Iran, North Korea, other-in alphabetic order), are considered connected with the world countries' union. Until North Korea, Iran, and others fulfill the necessary and sufficient conditions for establishing continuable political administration system in that countries, they are not proposed to be integrated any regional union nearby them. However, author proposed to establish ideal political construction with five structural groups within the North Korea, Iran and other countries, parallel to the fulfill procedure. There are three possible way of constructions proposed for the world countries' union: (a) establishment of new world countries' union due to (Case-D: Method-D1); (b) re-construction of the United Nations (UN) to establish new world countries' union (Case-D:Method-D2); or (c) establishment of new world countries' union, and integration of United Nations (UN) to this new system. In all cases (Method-D1 \& D2 \& D3), the world countries' union is considered as one of the important part for continuable administration system in the world. This continuable administration system for the world (the new one framework) defined with all its components in other work, generally/specifically, and it includes world countries' union, 20 regional unions, and Others. Author already gave some advices, supports, additions about establishment, and/or organization, and/or re-construction of these four case theory applications, and some of them are already realized until now. With this respect, some people can realize that the synthesis 
already made due to 21 dimensions, and all the problems are noticed generally and specifically. Which means the possible solutions and convergence points are already known, generally and specifically, and the "countries' union theory" and "political/non-political administration systems", all other related constructional and complementary theories are "good and correct" guide to solve these problems systematically. Author already solved some/most/all of problems (due to subjects of services) with the one unified framework, with the 20 regional unions, administration systems, each 11/12 blocs of the systems, with systems' administrations, with sense of justice and with other theories, ideologies, philosophies, sciences, methods gave above. It is noticed that some/most of the people ("experienced" or not, due to subjects of services) are already understand the subjects defined in this work and/or in the previous works "necessarily and sufficiently" (Ramiz, 2015; Ramiz, January 2016; others), and did "good" or "correct" applications accordingly. However, it is proposed to solve "some" other problems and/or to make some other realizations regarding the administration systems in short, mid or long period, and together and/or separately with the "some of these same people" and with some other "experienced" and "less experienced peoples" due to subjects of services considered.

\section{References}

Bucaille, M. (1973). The Bible, the Qur'an and science: The Holy Scritures examined in the Light of Modern Knowledge. (Book

Trans.). Mondial by Editions Seghers, Paris, The Socialist People's Libyan Arab Jamahiriyah, Tripoli.

Centrism. (2015, September). In Wikipedia. Retrieved from https://en.wikipedia.org/wiki/Centrism.

Commager, H. S. (n. d.). Living documents of American History. US Information Service.

Crotty, W. J., Freeman, D. M., \& Gatlin, D. S. (1971). Political parties and political behavior. Allyn and Bacon, Boston.

Democracy. (2015, June). In Wikipedia. Retrieved from https://en.wikipedia.org/wiki/Democracy

Ethnic Groups. (2015, October). In Wikipedia. Retrieved from https://en.wikipedia.org/wiki/List_of_contemporary_ethnic_groups

Ethnic Groups. (n.d.). The World Factbook. Retrieved from

https://www.cia.gov/library/publications/the-world-factbook/fields/2075.html

European Union. (2016, March). In Wikipedia. Retrieved from https://en.wikipedia.org/wiki/European_Union

Federation, (2016, March). In Wikipedia. Retrieved from https://en.wikipedia.org/wiki/Federation

Furnas, J. C. (1969). The Americans: A social history of the United States 1587-1914. Putnam.

Gigli, A. (1982). Insanlık ve Uygarlı Tarihi Ansiklopedisi (History of Humanity and Civilization Encyclopedia). Milliyet Yayınları.

Governance. (2015, October). In Wikipedia. Retrieved from https://en.wikipedia.org/wiki/Governance

Government. (2016, February). In Wikipedia. Retrieved from https://en.wikipedia.org/wiki/Government

Gülaltay, S. T. (2005). Tanrı'nın Türkleri. (Turks of God). Kafkas.

Ideology. (2015, October). In Wikipedia. Retrieved from https://en.wikipedia.org/wiki/Ideology

İşüden, T. (1982). Makro Íktisat (Macro Economy). BİLİM TEKNİK.

Laski, H. J. (1936). The state in theory and practice. London, Allen \& Unwin.

Law. (2015, October). In Wikipedia. Retrieved from https://en.wikipedia.org/wiki/Law

List of Constituent Monarchs. (2016, February). In Wikipedia. Retrieved from https://en.wikipedia.org/wiki/List_of_current_constituent_monarchs

List of National Legal Systems. (2015, August). In Wikipedia. Retrieved from https://en.wikipedia.org/wiki/List_of_national_legal_systems

List of Political Ideologies.(2010, May). In Wikepedia. Retrevied from https://en.wikipedia.org/wiki/List_of_political_ideologies

List of Religions. (2015, August). In Wikipedia. Retrieved from https://en.wikipedia.org/wiki/List_of_religions_and_spiritual_traditions.

List of Ruling Political Parties by Country. (2015, October). In Wikipedia. Retrieved from https://en.wikipedia.org/wiki/List_of_political_parties_by_country

List of Sovereign Monarchs. (2016, February). In Wikipedia. Retrieved from https://en.wikipedia.org/wiki/List_of_current_sovereign_monarchs 


\section{NEW ADMINISTRATION SYSTEMS FOR THE WORLD COUNTRIES AND SENSE OF JUSTICE}

Lord, A. R. (1931). The principles of politics: An introduction to the study of the evolution of political ideas. Oxford. Materialism. (2015, June). In Wikipedia. Retrieved from https://en.wikipedia.org/wiki/Materialism.

Mayor, F., \& Forti, A. (2000). Bilim ve İktidar.(Science and political Power). çev. M. Küçük, TÜBİTAK. Monetarism.(2015, June). In Wikipedia. Retrieved from https://en.wikipedia.org/wiki/Monetarism

Nationalism. (2016, February). In Wikipedia. Retrieved from https://en.wikipedia.org/wiki/Nationalism.

Neibuhr, R., \& Sigmund, P. E. (1969). The democratic experience: Past and prospects. Praeger.

Online Encyclopedias. (2015, May). In Wikipedia. Retrieved from https://en.wikipedia.org/wiki/List_of_online_encyclopedias

Party System. (2015, December). In Wikipedia. Retrieved from https://en.wikipedia.org/wiki/Party_system.

Philosophy. (2015, October). In Wikipedia. Retrieved from https://en.wikipedia.org/wiki/Philosophy

Pigors, P. , Myers, C. A., \& Malm, F. T. (1973). Management of human resources. McGraw-Hill.

Politics. (2015, June). In Wikipedia. Retrieved from https://en.wikipedia.org/wiki/Politics

Political Engineering. (2015, October). In Wikipedia. Retrieved from https://en.wikipedia.org/wiki/Political_engineering

Political History. (2015, June). In Wikipedia. Retreived from https://en.wikipedia.org/wiki/Political_history

Political Ideologies. (2015, October). In Wikipedia. Retrieved from https://en.wikipedia.org/wiki/Political_ideology

Political International. (2016, March). In Wikipedia. Retrieved from https://en.wikipedia.org/wiki/Political_international

Political Party. (2015, October). In Wikipedia. Retrieved from https://en.wikipedia.org/wiki/Political_party

Political Religion. (2016, February). In Wikipedia. Retrieved from https://en.wikipedia.org/wiki/Political_religion

Political Science. (2015, October). In Wikipedia. Retrieved from https://en.wikipedia.org/wiki/Political_science

Political Spectrum. (2015, October). In Wikipedia. Retrieved from https://en.wikipedia.org/wiki/Political_spectrum

Political Systems. (2015, October). In Wikipedia. Retrieved from https://en.wikipedia.org/wiki/Political_system

Population by Country. (2016, February). In Worldomete. Retrieved from http://www.worldometers.info/world-population/population-by-country/

Population of World Countries (2016, February). In Wikipedia. Retrieved from https://en.wikipedia.org/wiki/List_of_countries_and_dependencies_by_population

Progressivism. (2015, May). In Wikipedia. Retrieved from https://en.wikipedia.org/wiki/Progressivism.

Public Administration. (2015, October). In Wikipedia. Retrieved from https://en.wikipedia.org/wiki/Political_administration

Ramiz, R. (2015, September). A continuable political administration system for world countries-I. International Relations and Diplomacy, 3(9), 609-624.

Ramiz, R. (2016, January). A continuable political administration system for world countries-II. International Relations and Diplomacy, 4(1), 14-37.

Ramiz, R. (2016, March). Countries' Union and political/non-political administration systems for the world countries. International Relations and Diplomacy, 4(3), 139-176.

Religion. (2015, October). In Wikipedia. Retrieved from https://en.wikipedia.org/wiki/Religions

Religion and Mythology. (2016, February). In Wikipedia. Retrieved from https://en.wikipedia.org/wiki/Religion_and_mythology

Religion and Politics. (2016, March). In Internet Encyclopedia of Philosophy. Retrieved from http://www.iep.utm.edu/rel-poli/

Religion and Science.(2016, February). In Stanford Encyclopedia of Philosophy.

Retrieved from http://plato.stanford.edu/entries/religion-science/

Religion and Science. (2016, March). In Wikipedia. Retrieved from https://en.wikipedia.org/wiki/Relationship_between_religion_and_science

Religious Texts (Holy Books). (2016, February). In Wikipedia. Retrieved from https://en.wikipedia.org/wiki/Religious_text

Ronan, C. A. (1964). Man probes the universe. Aldus.

Science. (2015, May). In Wikipedia. Retrieved from https://en.wikipedia.org/wiki/Science.

Scientific Revolution . (2015, August). In Wikipedia. Retrieved from https://en.wikipedia.org/wiki/Scientific_revolution

Separation of Powers. (2015, May). In Wikipedia. Retrieved from https://en.wikipedia.org/wiki/Separation_of_powers.

System. (2015, September). In Wikipedia. Retrieved from https://en.wikipedia.org/wiki/System.

United Nations. (2010, May). In Wikipedia. Retrieved from https://en.wikipedia.org/wiki/United_Nations

Uyterhoeven, H. E. R., Ackerman, R. W., \& Rosenblum, J. W. (1973). Strategy and organization: Text and cases in general management. IRWIN.

Westfall, R. S. (2000). Modern Bilimin Oluşumu (The construction of modern science). çev. İ. H. Duru, TÜBİTAK.

Yücel, T. (1985). Türk ve Dünya Tarihi Ansiklopedisi (Turkish and World History Encyclopedia). çev., Gelişim-Hachette, Le Livre de Paris, S. N. C., Biblioclub de France. 